\title{
Malaria and immunity during pregnancy and postpartum: a tale of two species
}

\author{
A. R. D. MCLEAN ${ }^{1,2}$, R. ATAIDE ${ }^{1}$, J.A. SIMPSON ${ }^{2}$, J. G. BEESON ${ }^{1,3,4}$ and \\ F. J. I. FOWKES ${ }^{1,2,5}$ * \\ ${ }^{1}$ Macfarlane Burnet Institute of Medical Research, 85 Commercial Road, Melbourne, Victoria 3004, Australia \\ ${ }^{2}$ Centre for Epidemiology and Biostatistics, Melbourne School of Population and Global Health, The University of \\ Melbourne, Melbourne, Victoria, Australia \\ ${ }^{3}$ Department of Microbiology, Monash University, Melbourne, Victoria, Australia \\ ${ }^{4}$ Department of Medicine, University of Melbourne, Melbourne, Victoria, Australia \\ ${ }^{5}$ Department of Epidemiology and Preventive Medicine and Department of Infectious Diseases, Monash University, \\ Commercial Road, Melbourne, Victoria 3004, Australia
}

(Received 10 November 2014; revised 19 December 2014; accepted 16 Fanuary 2015; first published online 3 March 2015)

\begin{abstract}
SUMMARY
It is well established that pregnant women are at an increased risk of Plasmodium falciparum infection when compared to non-pregnant individuals and limited epidemiological data suggest Plasmodium vivax risk also increases with pregnancy. The risk of $P$. falciparum declines with successive pregnancies due to the acquisition of immunity to pregnancy-specific $P$. falciparum variants. However, despite similar declines in $P$. vivax risk with successive pregnancies, there is a paucity of evidence $P$. vivax-specific immunity. Cross-species immunity, as well as immunological and physiological changes that occur during pregnancy may influence the susceptibility to both $P$. vivax and $P$. falciparum. The period following delivery, the postpartum period, is relatively understudied and available epidemiological data suggests that it may also be a period of increased risk of infection to Plasmodium spp. Here we review the literature and directly compare and contrast the epidemiology, clinical pathogenesis and immunological features of $P$. vivax and $P$.falciparum in pregnancy, with a particular focus on studies performed in areas co-endemic for both species. Furthermore, we review the intriguing epidemiology literature of both $P$. falciparum and $P$. vivax postpartum and relate observations to the growing literature pertaining to malaria immunology in the postpartum period.
\end{abstract}

Key words: malaria, Plasmodium vivax, falciparum, pregnancy, postpartum, immunity, epidemiology.

\section{INTRODUCTION}

Malaria is a mosquito-borne infectious disease caused by the parasite Plasmodium, of which six species can infect humans; Plasmodium falciparum, Plasmodium vivax, Plasmodium ovale curtisi, Plasmodium ovale wallikeri, Plasmodium malariae and Plasmodium knowlesi. Of these, P. falciparum and $P$. vivax are the predominant species with an estimated $182 \cdot 2$ million clinical cases of $P$. falciparum malaria, 15.8 million clinical cases of P. vivax malaria and 584000 deaths attributable to malaria every year (WHO, 2014). The greatest burden of disease is seen in young children and pregnant women. $P$. falciparum is responsible for the vast majority of global morbidity and mortality (WHO, 2014). It is estimated that over 125 million pregnancies are at risk of malaria, 32 million are at risk of $P$. falciparum, 40 million are at risk of $P$. vivax and 53 million are at risk of both species) (Dellicour et al. 2010). Women who acquire a Plasmodium spp. infection during pregnancy commonly experience negative maternal and birth outcomes such as

* Corresponding author. Macfarlane Burnet Institute of Medical Research, 85 Commercial Road, Melbourne, Victoria 3004, Australia. E-mail: fowkes@burnet.edu.au anaemia, low birth weight and preterm birth with an estimated 75000-200 000 infant deaths annually attributable to malaria in pregnancy (Steketee et al. 2001). Malaria in the period following pregnancy, the postpartum period, is also of public health importance. Malaria was the leading indirect cause of death in postpartum women in a study in Zambia (Vallely et al. 2005) and the second highest cause of postpartum death in a study in India (Barnett et al. 2008).

In malaria endemic areas, individuals develop naturally acquired immunity to both $P$. falciparum and $P$. vivax after repeated infections. This immunity does not generally protect against infection per $s e$, but protects against the development of high parasite densities and clinical symptoms (reviewed in Langhorne et al. 2008). Despite acquiring a degree of protective immunity prior to pregnancy, pregnant women are typically more susceptible to $P$. falciparum and $P$. vivax. Broad hormonal and immunological changes that occur during pregnancy are likely to play a role, with a general shift from cellmediated immunity toward humoral immunity (Jamieson et al. 2006; Robinson and Klein, 2012). In the case of $P$. falciparum the increased susceptibility has been largely attributed to the lack of

Parasitology (2015), 142, 999-1015. C Cambridge University Press 2015. This is an Open Access article, distributed under the terms of the Creative Commons Attribution licence (http://creativecommons.org/licenses/by/3.0/), which permits unrestricted re-use, distribution, and reproduction in any medium, provided the original work is properly cited. 
Table 1. Plasmodium vivax risk in pregnancy compared to non-pregnant women and comparisons with $P$. falciparum risk in co-endemic areas

\begin{tabular}{|c|c|c|c|c|c|}
\hline Study & Country & $\begin{array}{l}\text { Plasmodium } \\
\text { vivax }\end{array}$ & $\begin{array}{l}\text { Magnitude } \\
(95 \% \text { CI })\end{array}$ & $\begin{array}{l}\text { Plasmodium } \\
\text { falciparum }\end{array}$ & $\begin{array}{l}\text { Magnitude } \\
(95 \% \mathrm{CI})\end{array}$ \\
\hline \multicolumn{6}{|l|}{ Risk/odds of infection } \\
\hline Campbell et al. (1980) & $\begin{array}{l}\text { El } \\
\text { Salvador }\end{array}$ & Similar & $\begin{array}{l}\mathrm{RR}=1 \cdot 13 \\
\quad(0 \cdot 83,1 \cdot 53)^{\mathrm{a}}\end{array}$ & Increased & $\begin{array}{l}\mathrm{RR}=1.23 \\
\quad(0.93,1.63)^{\mathrm{a}}\end{array}$ \\
\hline Singh et al. $(1995)^{\mathrm{b}}$ & India & Increased & $\begin{array}{l}\mathrm{OR}=1 \cdot 30 \\
(0 \cdot 82,2 \cdot 06)^{\mathrm{a}}\end{array}$ & Increased & $\begin{array}{l}\mathrm{OR}=2 \cdot 34 \\
(1 \cdot 63,3 \cdot 37)^{\mathrm{a}}\end{array}$ \\
\hline Singh et al. $(1999)^{\mathrm{b}}$ & India & Increased & $\begin{array}{l}\mathrm{OR}=3 \cdot 36 \\
(2 \cdot 28,5 \cdot 07)^{\mathrm{a}}\end{array}$ & Increased & $\begin{array}{l}\mathrm{OR}=2 \cdot 11 \\
(1 \cdot 66,2 \cdot 68)^{\mathrm{a}}\end{array}$ \\
\hline Parekh et al. (2007) & Peru & Similar & $\begin{array}{l}\mathrm{RR}=0.92 \\
(0.52,1.64)\end{array}$ & Increased & $\begin{array}{l}\mathrm{RR}=2 \cdot 28 \\
(1 \cdot 32,3 \cdot 95)\end{array}$ \\
\hline \multicolumn{6}{|l|}{ Multiplicity of infection } \\
\hline $\begin{array}{l}\text { Marin-Menendez et al. } \\
\quad \text { (2013) }\end{array}$ & Brazil & Similar MOI & $\begin{array}{l}1 \cdot 17 \text { MOI vs } 1 \cdot 17 \\
\text { MOI }\end{array}$ & $\mathrm{N} / \mathrm{A}$ & $\mathrm{N} / \mathrm{A}$ \\
\hline $\begin{array}{l}\text { Thanapongpichat et al. } \\
\text { (2013) }\end{array}$ & Thailand & Increased MOI & $\begin{array}{l}\text { 2.03 MOI vs } 1 \cdot 65 \\
\text { MOI }\end{array}$ & $\mathrm{N} / \mathrm{A}$ & $\mathrm{N} / \mathrm{A}$ \\
\hline \multicolumn{6}{|c|}{ Species-specific parasite mean density } \\
\hline (Campbell et al. 1980) & $\begin{array}{l}\text { El } \\
\text { Salvador }\end{array}$ & Increased & $\begin{array}{l}\mathrm{MD}=+1615 / \\
\mathrm{mm}^{3 \mathrm{a}}\end{array}$ & Increased & $\begin{array}{l}\mathrm{MD}=+3093 / \\
\mathrm{mm}^{3 \mathrm{a}}\end{array}$ \\
\hline$\left(\right.$ Singh et al. 1999) ${ }^{\mathrm{b}}$ & India & Increased & $\begin{array}{l}\mathrm{MD}=+11369 / \\
\mathrm{mm}^{3 \mathrm{a}}\end{array}$ & Increased & $\begin{array}{l}\mathrm{MD}=+8265 / \\
\mathrm{mm}^{3 \mathrm{a}}\end{array}$ \\
\hline Species ratio & & $\mathrm{Pv}_{\mathrm{v}} \mathrm{Pf}$ & & Pf:Pv & \\
\hline $\begin{array}{l}\text { Martinez-Espinosa et al. } \\
\quad(2004) \dagger\end{array}$ & Brazil & Decreased & $2 \cdot 3: 1$ vs $5 \cdot 6: 1$ & Increased & $1: 2 \cdot 3$ vs $1: 5 \cdot 6$ \\
\hline Barcus et al. $(2007)^{\mathrm{c}}$ & Indonesia & Increased & $1: 2 \cdot 6$ vs $1: 3 \cdot 7$ & Decreased & $2 \cdot 6: 1$ vs $3 \cdot 7: 1$ \\
\hline Almeida et al. $(2010)^{\mathrm{b}}$ & Brazil & Similar & $5 \cdot 8: 1$ vs $5 \cdot 5: 1$ & Similar & $1: 5 \cdot 8$ vs $1: 5 \cdot 5$ \\
\hline
\end{tabular}

$\mathrm{NB}$ - ratios within $0 \cdot 2$ of 1 were considered similar to 1 . Abbreviations: MD, mean difference; OR, odds ratio; RR, risk ratio; N/A, not available; MOI, multiplicity of infections. All measures of association are unadjusted unless otherwise specified.

${ }^{a}$ Calculated from data in paper.

b Women in study restricted to those with history of fever.

c Women with slide-confirmed diagnoses of malaria.

immunity to pregnancy-specific isolates that sequester in the placenta (well documented and extensively reviewed elsewhere, e.g. (Desai et al. 2007; Duffy, 2007; Hviid and Salanti, 2007; Rogerson, 2010; Umbers et al. 2011)). The ability of $P$. vivax to bind and sequester in the placenta, its role in pathogenesis and the role of immunity against this process are debated (Mayor et al. 2012a). Importantly, $P$. vivax possesses the ability to form hypnozoites in the liver, a dormant stage which can lead to relapses of blood-stage infections (Krotoski et al. 1982; Krotoski, 1985). The immunological mechanisms that mitigate $P$. vivax in pregnancy are unclear, as is the effect of an altered immunological state during pregnancy on the risk of relapse.

The rate at which a woman returns to a normal immunological state after pregnancy, and how this affects malaria risk postpartum has not been well characterized. There is increasing evidence for the altered susceptibility to $P$. falciparum and $P$. vivax postpartum (Boel et al. 2012) and a growing literature investigating the immune response to malaria in the postpartum period which may account for observed epidemiological patterns. In this review we highlight the similarities and differences of $P$.vivax and $P$. falciparum infection during pregnancy and the postpartum period with respect to epidemiology, clinical pathogenesis and immunology.

\section{Plasmodium falciparum and P. vivax risk in pregnancy}

Numerous studies have demonstrated that pregnant women are at increased risk of P. falciparum infection and experience higher parasite densities and rates of clinical malaria when compared to non-pregnant women (reviewed in Desai et al. 2007). We therefore reviewed the $P$. vivax literature in addition to studies investigating $P$. vivax and $P$. falciparum in co-endemic areas. Few studies have investigated the risk of $P$. vivax infection during pregnancy and available data is conflicting (Table 1). An increased risk of $P$. vivax infection (Singh et al. 1995, 1999) and increased density of $P$. vivax infections (Campbell et al. 1980; Singh et al. 1999) have been observed in pregnant compared to non-pregnant women from El Salvador and India (Table 1). An increased multiplicity of $P$. vivax infections during pregnancy in Thailand has also been observed (Thanapongpichat et al. 2013) though no difference was observed in Brazil (Marin-Menendez et al. 2013). Other studies have failed to detect substantial 
Table 2. Adverse maternal outcomes due to $P$. vivax infection in pregnancy compared to non-infected pregnant women and comparisons with $P$. falciparum risk in co-endemic areas

\begin{tabular}{|c|c|c|c|c|c|}
\hline Study & Country & $\begin{array}{l}\text { Plasmodium } \\
\text { vivax }\end{array}$ & Magnitude (95\% CI) & $\begin{array}{l}\text { Plasmodium } \\
\text { falciparum }\end{array}$ & Magnitude $(95 \% \mathrm{CI})$ \\
\hline \multicolumn{6}{|l|}{ Risk/odds of anaemia } \\
\hline $\begin{array}{l}\text { Nair and Nair } \\
\quad(1993)^{\mathrm{a}}\end{array}$ & India & Increased $^{\mathrm{b}}$ & $\begin{array}{l}\mathrm{OR}=1 \cdot 24 \\
(0 \cdot 53,2 \cdot 81)^{\mathrm{c}}\end{array}$ & Increased $^{\mathrm{b}}$ & $\mathrm{OR}=3 \cdot 22(1 \cdot 53,6 \cdot 78)^{\mathrm{c}}$ \\
\hline Nosten et al. (1999) & Thailand & Increased $^{\mathrm{d}}$ & $\begin{array}{l}\mathrm{OR}=1.91 \\
(1.42,2.56)^{\mathrm{e}}\end{array}$ & $\mathrm{N} / \mathrm{A}$ & $\mathrm{N} / \mathrm{A}$ \\
\hline $\begin{array}{l}\text { Dreyfuss et al. } \\
\quad(2000)\end{array}$ & Nepal & Increased $^{\mathrm{f}}$ & $\begin{array}{l}\mathrm{OR}=2 \cdot 24 \\
\quad(0 \cdot 91,5 \cdot 52)^{\mathrm{g}}\end{array}$ & $\mathrm{N} / \mathrm{A}$ & $\mathrm{N} / \mathrm{A}$ \\
\hline \multicolumn{6}{|c|}{ Mean difference in haemoglobin } \\
\hline Singh et al. (1999) ${ }^{\mathrm{a}}$ & India & Decreased & $\begin{array}{l}\mathrm{MD}=-0.98 \mathrm{~g} \mathrm{dl}^{-1} \\
(-1 \cdot 11,-0 \cdot 85)^{\mathrm{c}}\end{array}$ & Decreased & $\begin{array}{l}\mathrm{MD}=-3 \cdot 61 \mathrm{~g} \mathrm{dl}^{-1} \\
(-3 \cdot 76,-3 \cdot 46)^{\mathrm{c}}\end{array}$ \\
\hline $\begin{array}{l}\text { Poespoprodjo et al. } \\
\text { (2008) }\end{array}$ & Indonesia & Decreased & $\begin{array}{l}\mathrm{MD}=-0 \cdot 4 \mathrm{~g} \mathrm{dl}^{-1} \\
(0 \cdot 7,-0 \cdot 1)\end{array}$ & Decreased & $\begin{array}{l}\mathrm{MD}=-1 \cdot 1 \mathrm{~g} \mathrm{dl}^{-1} \\
(-1 \cdot 4,-1 \cdot 0)\end{array}$ \\
\hline Yasnot et al. (2013) & Colombia & Similar & $\begin{array}{l}\mathrm{MD}=-0.1 \mathrm{~g} \mathrm{dl}^{-1} \\
(-1.29,1.09)\end{array}$ & $\mathrm{N} / \mathrm{A}$ & $\mathrm{N} / \mathrm{A}$ \\
\hline $\begin{array}{l}\text { Machado Filho } \\
\text { et al. (2014) }\end{array}$ & Brazil & Decreased & $\begin{array}{c}\mathrm{MD}=1 \cdot 2 \mathrm{~g} \mathrm{dl}^{-1} \\
(-1 \cdot 79,-0 \cdot 61)\end{array}$ & $\mathrm{N} / \mathrm{A}$ & N/A \\
\hline
\end{tabular}

$\mathrm{NB}$ - ratios within 0.2 of 1 and mean differences of less than $0.2 \mathrm{~g} \mathrm{dl}^{-1}$ were considered similar. All measures of association are unadjusted unless otherwise specified. Abbreviations: MD, mean difference; OR, odds ratio; N/A, not available.

a Women in study restricted to those with history of fever.

b Anaemia defined as $<8 \mathrm{hb} \mathrm{g} \mathrm{dl}^{-1}$.

c Calculated from data in paper.

d Anaemia defined clinically or by haematocrit $<30 \%$.

e Adjusted for age, location, gestational age at first visit, compliance to attendance at the antenatal clinic.

f Anaemia defined as $<11 \mathrm{hb} \mathrm{g} \mathrm{dl}^{-1}$.

$\mathrm{g}$ Adjusted for hookworm infection, vitamin A deficiency and trimester of pregnancy.

differences in $P$. vivax risk between pregnant women and non-pregnant women (Campbell et al. 1980; Parekh et al. 2007) ('Table 1). Furthermore, a study in Brazil found an increased frequency of $P$. falciparum relative to $P$. vivax infections in pregnant compared to non-pregnant women (MartinezEspinosa et al. 2004). However, another study from the same Brazilian population failed to replicate these findings (Almeida et al. 2010) and to further complicate matters, a study in Indonesia found an increased frequency of $P$. vivax relative to $P$. falciparum in pregnancy (Barcus et al. 2007) (Table 1). The available evidence is somewhat conflicting but together suggests that there is an increased risk of $P$. vivax infection during pregnancy compared to non-pregnancy, albeit a smaller increased risk than that observed in regards to pregnancy and $P$. falciparum infection.

The clinical consequences of Plasmodium infection occur during the blood-stage of infection and are exacerbated by high densities of the bloodstage parasite. P. falciparum invades all erythrocytes, whereas $P$. vivax selectively invades young erythrocytes (reticulocytes), and thus $P$. vivax parasitaemia is typically lower than $P$. falciparum parasitaemia (Collins and Jeffery, 1999a, b; Simpson et al. 1999; Collins et al. 2004). P. vivax has a lower pyrogenic threshold compared to $P$. falciparum, provoking a stronger inflammatory response for a given level of parasitaemia (Ross and Thomson, 1910;
Luxemburger et al. 1996; Hemmer et al. 2006; Yeo et al. 2010). However, P. vivax infections less frequently progress to severe disease compared to $P$. falciparum infections, which can result in cerebral malaria, metabolic acidosis, respiratory distress and severe anaemia. $P$. vivax can lead to severe clinical symptoms such as severe anaemia, respiratory distress and thrombocytopenia (reviewed in Anstey et al. 2012).

Few studies have investigated the relative severity of $P$. falciparum compared to $P$. vivax during pregnancy on maternal outcomes in co-endemic populations. Most studies show that $P$. falciparum is associated with more severe maternal and birth outcomes (Tables 2 and 3). Studies in Thailand, India and Indonesia have demonstrated that pregnant women infected with $P$. falciparum have increased severity and odds of anaemia compared to those infected with P. vivax (Nair and Nair, 1993; Nosten et al. 1999; Singh et al. 1999; Poespoprodjo et al. 2008). Interestingly, a study in Thailand has indicated a potential interaction in disease severity between the two species demonstrating a protective effect of $P$. vivax infection against severity and number of $P$. falciparum episodes during pregnancy (Luxemburger et al. 1997; Nosten et al. 1999). Both $P$. falciparum and $P$. vivax infections during pregnancy are associated with detrimental birth outcomes such as low birth weight, preterm delivery and miscarriage (Table 3 ). Studies conducted in 
Table 3. Adverse birth outcomes due to $P$. vivax infection in pregnancy compared to non-infected pregnant women and comparisons with $P$. falciparum risk in coendemic areas

\begin{tabular}{|c|c|c|c|c|c|}
\hline Study & Country & Plasmodium vivax & Magnitude (95\% CI) & Plasmodium falciparum & Magnitude (95\% CI) \\
\hline \multicolumn{6}{|l|}{ Risk/odds of low birth weight } \\
\hline McGready et al. $(2004)^{\mathrm{a}}$ & Thailand & Decreased & $\mathrm{OR}=0 \cdot 31(0 \cdot 01,4 \cdot 21)^{\mathrm{b}}$ & Increased & $\mathrm{OR}=1 \cdot 76(0 \cdot 44,10 \cdot 18)^{\mathrm{b}}$ \\
\hline Poespoprodjo et al. (2008) & Indonesia & Increased & $\mathrm{OR}=1 \cdot 9(1 \cdot 2,3 \cdot 1)$ & Increased & $\mathrm{OR}=1.9(1.4,2 \cdot 7)$ \\
\hline Tobon-Castano et al. (2011) & Colombia & Increased & $\mathrm{RR}=1 \cdot 26(0 \cdot 80,1 \cdot 98)^{\mathrm{b}}$ & Increased & $\mathrm{RR}=2 \cdot 12(1 \cdot 24,3 \cdot 60)^{\mathrm{b}}$ \\
\hline \multicolumn{6}{|l|}{ Mean difference in birth weight } \\
\hline Nosten et al. (1991) & Thailand & Similar & $\mathrm{MD}=-49 \mathrm{~g}^{\mathrm{b}}$ & Decreased & $\mathrm{MD}=-128 \mathrm{~g}^{\mathrm{b}}$ \\
\hline Nair and Nair $(1993)^{c}$ & India & Decreased & $\mathrm{MD}=-390 \mathrm{~g}^{\mathrm{b}}$ & Decreased & $\mathrm{MD}=-780 \mathrm{~g}^{\mathrm{b}}$ \\
\hline Nosten et al. (1999) & Thailand & Decreased $^{\mathrm{d}}$ & $\mathrm{MD}=-107 \mathrm{~g}(-154,61)^{\mathrm{b}}$ & $\mathrm{N} / \mathrm{A}$ & $\mathrm{N} / \mathrm{A}$ \\
\hline Singh et al. $(1999)^{\mathrm{c}}$ & India & Decreased & $\mathrm{MD}=-310 \mathrm{~g}(-356,-264)^{\mathrm{b}}$ & Decreased & $\mathrm{MD}=-380 \mathrm{~g}(-425,-335)^{\mathrm{b}}$ \\
\hline McGready et al. $(2004)^{\mathrm{a}}$ & Thailand & Similar & $\mathrm{MD}=-10 \mathrm{~g}(-182,162)^{\mathrm{b}}$ & Decreased & $\mathrm{MD}=-80 \mathrm{~g}(-288,128)^{\mathrm{b}}$ \\
\hline Poespoprodjo et al. (2008) & Indonesia & Decreased & $\mathrm{MD}=-108 \mathrm{~g}(-199,-18)$ & Decreased & $\mathrm{MD}=-192 \mathrm{~g}(-265,-119)$ \\
\hline Arango et al. (2013) & Colombia & Decreased & $\mathrm{MD}=-525 \mathrm{~g}(-780,-270)^{\mathrm{b}}$ & Decreased & $\mathrm{MD}=-278 \mathrm{~g}(-771,215)^{\mathrm{b}}$ \\
\hline Yasnot et al. (2013) & Colombia & Decreased & $\mathrm{MD}=-215 \mathrm{~g}(-539,109)^{\mathrm{b}}$ & N/A & N/A \\
\hline Machado Filho et al. (2014) & Brazil & Decreased & $\mathrm{MD}=-434 \mathrm{~g}(-742,-127)^{\mathrm{b}}$ & $\mathrm{N} / \mathrm{A}$ & $\mathrm{N} / \mathrm{A}$ \\
\hline \multicolumn{6}{|l|}{ Risk/odds of preterm delivery } \\
\hline Nair and Nair $(1993)^{c}$ & India & Increased & $\mathrm{OR}=7 \cdot 07(3 \cdot 02,16 \cdot 7)^{\mathrm{b}}$ & Increased & $\mathrm{OR}=9 \cdot 17(4 \cdot 02,21 \cdot 1)^{\mathrm{b}}$ \\
\hline McGready et al. $(2004)^{\mathrm{e}}$ & Thailand & Similar & $\mathrm{OR}=1 \cdot 00(0 \cdot 01,81 \cdot 3)^{\mathrm{b}}$ & Increased & $\mathrm{OR}=3 \cdot 5(0 \cdot 46,157 \cdot 2)^{\mathrm{b}}$ \\
\hline Tobon-Castano et al. (2011) & Colombia & Increased & $\mathrm{RR}=1.47(0.95,2 \cdot 28)$ & Increased & $\mathrm{RR}=3 \cdot 17(2 \cdot 02,4 \cdot 97)$ \\
\hline \multicolumn{6}{|l|}{ Mean difference in gestational age } \\
\hline Nosten et al. (1999) & Thailand & Similar & $\mathrm{MD}=0$ weeks $(-0 \cdot 3,0 \cdot 3)^{\mathrm{b}}$ & Similar & $\mathrm{MD}=-0 \cdot 2$ weeks $(-0 \cdot 4,0.0)^{\mathrm{b}}$ \\
\hline McGready et al. $(2004)^{\mathrm{e}}$ & Thailand & Similar & $\mathrm{MD}=0.5$ weeks $(-0.79,1.79)^{\mathrm{b}}$ & Similar & $\mathrm{MD}=-0.4$ weeks $(-1.35,0.55)^{\mathrm{b}}$ \\
\hline Yasnot et al. (2013) & Colombia & Decreased & MD $=-1.9$ weeks $(-3 \cdot 11,-0 \cdot 69)$ & N/A & N/A \\
\hline Machado Filho et al. (2014) & Brazil & Decreased & $\mathrm{MD}=-2$ weeks & $\mathrm{N} / \mathrm{A}$ & $\mathrm{N} / \mathrm{A}$ \\
\hline \multicolumn{6}{|l|}{ Odds of miscarriage } \\
\hline Nair and Nair $(1993)^{c}$ & India & Increased & $\mathrm{OR}=4 \cdot 64(0 \cdot 63,52 \cdot 4)^{\mathrm{b}}$ & Increased & $\mathrm{OR}=20 \cdot 4(4 \cdot 40,187)^{\mathrm{b}}$ \\
\hline Nosten et al. (1999) & Thailand & Decreased & $\mathrm{OR}=0.65(0.41,0.97)^{\mathrm{b}, \mathrm{f}}$ & $\mathrm{N} / \mathrm{A}$ & $\mathrm{N} / \mathrm{A}$ \\
\hline \multirow[t]{2}{*}{ McGready et al. (2012) } & Thailand & Increased $^{\mathrm{g}}$ & $\mathrm{OR}=3.99(3 \cdot 10,5 \cdot 13)^{\mathrm{h}, \mathrm{i}}$ & Increased $^{g}$ & $\mathrm{OR}=3.99(3 \cdot 10,5 \cdot 13)^{\mathrm{h}, \mathrm{i}}$ \\
\hline & & & $\mathrm{OR}=2.70(2 \cdot 04,3.59)^{\mathrm{h}, \mathrm{j}}$ & & $\mathrm{OR}=2 \cdot 70(2 \cdot 04,3 \cdot 59)^{\mathrm{h}, \mathrm{j}}$ \\
\hline
\end{tabular}

$\mathrm{NB}$ - ratios within $0 \cdot 2$ of 1 were considered similar to 1 . Birth weight MDs $<50$ g were considered similar. Gestational age MDs $<1$ week were considered similar. Low birth weight defined as $<2500 \mathrm{~g}$. All measures of association are unadjusted unless otherwise specified. Abbreviations: MD, mean difference; OR, odds ratio; RR, Risk Ratio.

a Cases included P. malariae and P. vivax cases.

b Calculated from data in paper.

c Women in study restricted to those with history of fever.

d Adjusted for age, location, gestational age at first visit, compliance to attendance at the antenatal clinic.

e Adjusted for hookworm infection, vitamin A deficiency and trimester of pregnancy.

Error in the published paper, the reported events in the $P$. vivax group should read 447, not 44 . Confirmed by authors of the paper.

S Single episode of $P$. vivax or $P$. falciparum in first trimester.

h Adjusted for age, smoking and estimated gestational age.

i Symptomatic malaria.

j Asymptomatic malaria 
Thailand, India, Colombia and Indonesia have tended to find a greater reduction in birth weight and greater increase in the risk of preterm delivery amongst pregnant women with $P$. falciparum infections compared to $P$. vivax infections in pregnancy (Nair and Nair, 1993; Nosten et al. 1999; Singh et al. 1999; McGready et al. 2004; Poespoprodjo et al. 2008; Tobon-Castano et al. 2011) (Table 3). A study in India showed reduced odds of foetal loss in $P$. vivax compared to P. falciparum infections (Nair and Nair, 1993), whereas studies in Thailand which have specifically examined miscarriage found similar odds in $P$. falciparum and $P$. vivax infections (McGready et al. 2012). Taken together the above findings suggest that some of the underlying mechanisms by which the two species mediate negative birth outcomes are independent.

It is well documented that the risk of $P$. falciparum infection during pregnancy is highest amongst primigravid women (reviewed in Desai et al. 2007). Studies in Thailand, India and Indonesia have also found that primigravidae are more at risk of $P$. vivax infection than multigravidae (Brabin et al. 1990; Singh et al. 1998, 1999; Nosten et al. 1999; Poespoprodjo et al. 2008; Fowkes et al. 2012), although this finding is not consistent across all study sites (Singh et al. 1995; Luxemburger et al. 2001; Appleyard et al. 2008) (Table 4). Broad immunological and hormonal changes that take place with successive pregnancies could play a role in the decreasing risk of both $P$. falciparum and $P$. vivax with gravidity (Vleugels et al. 1987, 1989; Riley et al. 1989; Bouyou-Akotet et al. 2004, 2005). Additionally, a degree of protective immunity is acquired to both species during pregnancy, which may play a stronger role in $P$. falciparum infections than $P$. vivax infections (reviewed below).

A review of the epidemiological data indicates that consolidation of data is challenging due to differences in transmission and clinical criteria. In summary, the data suggest that pregnant women may be at an increased risk of $P$. vivax during pregnancy, but are relatively more susceptible to $P$. falciparum than $P$. vivax compared to their non-pregnant counterparts. Infection with $P$. falciparum during pregnancy tends to lead to more severe negative maternal and birth outcomes than infection with $P$. vivax. Evidence suggests that primigravidae are at increased risk of $P$. falciparum and $P$. vivax compared to multigravidae. The differential risk, severity and gravidity effects could be attributed to the distinct pathologies of $P$. falciparum and $P$. vivax during pregnancy and/or differential immunity to the two species.

Key differences in P.falciparum and $P$. vivax clinical pathogenesis

During pregnancy, specific $P$. falciparum variants emerge that can escape pre-existing immunity and

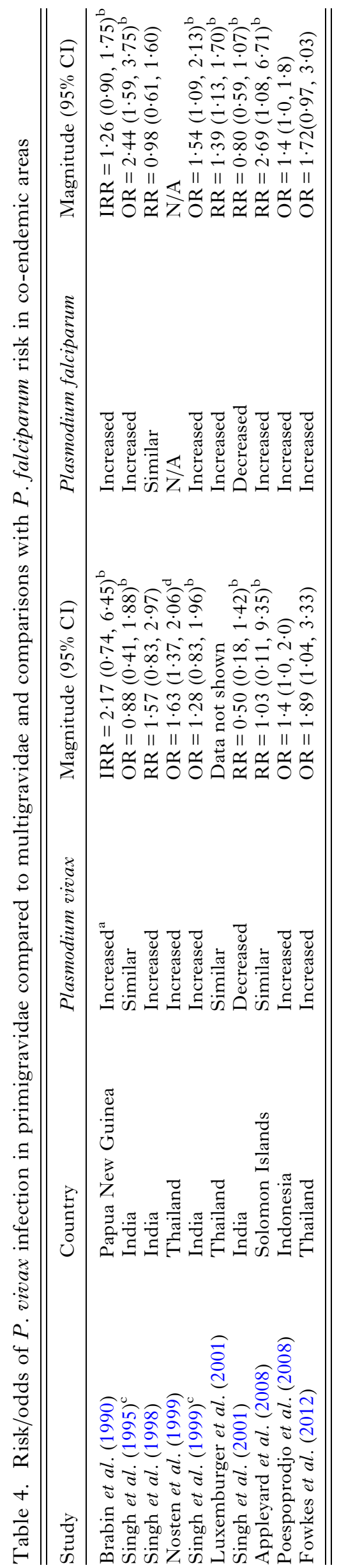


Table 5. Key differences in P. falciparum and P. vivax placental and binding pathogenesis

\begin{tabular}{|c|c|c|c|c|}
\hline \multirow{2}{*}{ Feature } & \multicolumn{2}{|l|}{ Plasmodium vivax } & \multicolumn{2}{|c|}{ Plasmodium falciparum } \\
\hline & Finding & References & Finding & References \\
\hline $\begin{array}{l}\text { Infections detected in } \\
\text { placenta }\end{array}$ & Rare & $\begin{array}{l}\text { Singh et al. (2003) Mayor } \\
\text { et al. }(2012 \text { a) Carmona- } \\
\text { Fonseca } \text { et al. }(2013)\end{array}$ & Common & Singh et al. (2003) \\
\hline $\begin{array}{l}\text { Altered placental } \\
\text { histology }\end{array}$ & $\begin{array}{l}\text { Yes (less severe } \\
\text { than } P f)\end{array}$ & $\begin{array}{l}\text { McGready et al. (2004) } \\
\text { Souza et al. }(2013)\end{array}$ & $\begin{array}{l}\text { Yes (more severe } \\
\text { than } P v)\end{array}$ & $\begin{array}{l}\text { McGready et al. } \\
\text { (2004) Souza } \text { et al. } \\
\text { (2013) }\end{array}$ \\
\hline $\begin{array}{l}\text { Binding to placental } \\
\text { cryosection in vitro }\end{array}$ & $\begin{array}{l}\text { Yes (decreased } \\
\text { binding com- } \\
\text { pared to } P f \text { ) }\end{array}$ & Carvalho et al. (2010) & $\begin{array}{l}\text { Yes (increased } \\
\text { binding compared } \\
\text { to } P v)\end{array}$ & $\begin{array}{l}\text { Carvalho et al. } \\
\text { (2010) }\end{array}$ \\
\hline $\begin{array}{l}\text { Binding to Chondroitin } \\
\text { Sulphate-A in vitro }\end{array}$ & Yes & Chotivanich et al. (2012) & Yes & $\begin{array}{l}\text { Fried and Duffy } \\
\text { (1996) }\end{array}$ \\
\hline $\begin{array}{l}\text { Binding to hyaluronic } \\
\text { acid in vitro }\end{array}$ & Yes & Chotivanich et al. (2012) & Yes & Beeson et al. (2000) \\
\hline Binding to $\operatorname{IgG}$ in vitro & Unknown & $\mathrm{N} / \mathrm{A}$ & Yes & Flick et al. (2001) \\
\hline Binding to IgM in vitro & Unknown & $\mathrm{N} / \mathrm{A}$ & Yes & Creasey et al. (2003) \\
\hline $\begin{array}{l}\text { Differential binding in } \\
\text { pregnancy compared to } \\
\text { non-pregnancy isolates }\end{array}$ & No & $\begin{array}{l}\text { Marin-Menendez et al. } \\
\text { (2013) }\end{array}$ & Yes & $\begin{array}{l}\text { Fried and Duffy } \\
\text { (1996) Beeson et al. } \\
\text { (1999) }\end{array}$ \\
\hline $\begin{array}{l}\text { Leading placental ligand } \\
\text { candidate }\end{array}$ & $\begin{array}{l}\text { Members of the } \\
\text { VIR family }\end{array}$ & $\begin{array}{l}\text { (Carvalho et al. 2010; } \\
\text { Chotivanich } \text { et al. 2012) }\end{array}$ & PfVAR2CSA & Salanti et al. (2003) \\
\hline Rosetting & Yes & Udomsanpetch et al. (1995) & $\begin{array}{l}\text { Yes (uncommon in } \\
\text { placental isolates) }\end{array}$ & $\begin{array}{l}\text { Handunnetti et al. } \\
\text { (1989) Rogerson } \\
\text { et al. }(2000)\end{array}$ \\
\hline
\end{tabular}

Abbreviations: Pf, Plasmodium falciparum; Pv, Plasmodium vivax; IgG, immunoglobulin G; IgM, immunoglobulin M; N/A, not available.

sequester in the placenta. Plasmodium falciparum isolates in pregnant women upregulate the expression of PfVAR2CSA, an antigen located on the $P$. falciparum-infected erythrocyte (Pf-IE) surface. PfVAR2CSA is a specific form of the variant protein PfEMP1 (P. falciparum erythrocyte membrane protein 1) that binds to placental chondroitin-sulphate A (CSA) and helps mediate parasite sequestration in the placenta (reviewed in Khunrae et al. 2010). The increased burden and detrimental effects of $P$. falciparum infection observed in pregnant women has been largely attributed to elevated parasite densities and the placental sequestration of $P f$-IEs (reviewed in Desai et al. 2007; Hviid and Salanti, 2007; Rogerson, 2010; Umbers et al. 2011). Plasmodium falciparum infection during pregnancy is typically associated with a very pronounced sequestration, or selective accumulation, of mature forms of blood-stage parasites in the placenta with a parasitaemia many fold higher than that observed in the peripheral blood (Walter et al. 1982; Beeson et al. 2002). The accumulation of large numbers of $P f$-IEs at the placenta results in changes to placental histology including inflammation, deposition of pigment in fibrin or inflammatory cells, syncytial knotting and thickening of the trophoblastic basement membrane (Walter et al. 1982; Bulmer et al. 1993; Ismail et al. 2000; Rogerson et al. 2003). P. vivax lacks the PfVAR2CSA protein, or any known PfVAR2CSA orthologues, and $P$. vivax-IEs
(Pv-IEs) are rarely found in the placenta (Singh et al. 2003; Mayor et al. 2012a; Carmona-Fonseca et al. 2013). Despite this, infections with P. vivax during pregnancy have been associated with some of the same histological changes observed in $P$. falciparum infections, though these changes are typically less severe (McGready et al. 2004; Souza et al. 2013) (Table 5). The binding of $P v$-IEs to CSA (as well as other endothelial cells) has been described in vitro and may be partly mediated by PvVIR (Variant Interspersed Repeats) proteins expressed on the surface of Pv-IEs. However, the level of cytoadhesion of Pv-IEs to CSA is around ten-fold lower than that displayed by $P f$-IEs (Carvalho et al. 2010; Chotivanich et al. 2012) and cytoadherence to CSA does not differ between $P$. vivax isolates from pregnant and non-pregnant individuals (Marin-Menendez et al. 2013). The low level of CSA-adherence exhibited by $P v$-IEs likely plays a minor role in pathogenesis compared to $P$. falciparum. The existence of PfVAR2CSA in P. falciparum represents a crucial difference between the two species and explains much of the different infection outcomes experienced by pregnant women. The reduced level of $P$. vivax cytoadhesion in vitro relative to $P$. falciparum explains the rarity of clinical observations of $P$. vivax placental sequestration (Mayor et al. 2012a; Carmona-Fonseca et al. 2013; Souza et al. 2013; Chaikitgosiyakul et al. 2014). Although other ligand/receptor combinations 
have been proposed as contributing to the sequestration of parasites in the placenta (Table 5) the evidence currently favours PfVAR2CSA/CSA as the principal interaction responsible for placental sequestration of $P$. falciparum.

Another pathophysiological feature mediated by IE surface ligands is rosetting, whereby IEs bind to uninfected erythrocytes. Rosetting is a feature of both $P$. falciparum and $P$. vivax isolates from infections in non-pregnant individuals (Udeinya et al. 1981; Udomsanpetch et al. 1995). Recent evidence suggests that rosetting occurs more frequently in $P$. vivax isolates than $P$. falciparum isolates (Lee et al. 2014) likely due to differential erythrocyte or receptor preferences. Glycophorin $\mathrm{C}$ is a ligand for both $P$. falciparum and $P$. vivax rosetting (Lee et al. 2014) whilst numerous other receptors have been identified for P. falciparum rosetting (reviewed in Sherman et al. 2003). Interestingly, rosetting is uncommon in placental $P$. falciparum isolates (Maubert et al. 1998; Rogerson et al. 2000) and is lacking in isolates that adhere to CSA and upregulate VAR2CSA (Beeson and Brown, 2004). In the absence of placental sequestration, the rosetting phenotype may contribute more strongly to clinical outcomes in $P$. vivax infection; rosetting is strongly associated with anaemia and increased parasitaemia in both P. falciparum and P. vivax infection (Rowe et al. 2002; Doumbo et al. 2009; Marin-Menendez et al. 2013).

In the absence of considerable interactions between the placenta and $P v$-IEs, the altered placental histology associated with $P$. vivax infection is likely due to broad effects of peripheral infection, such as maternal anaemia, fever or the effect of the cytokine response to infection (Mayor et al. 2012a; Souza et al. 2013). These mechanisms likely also act in $P$. falciparum peripheral infections in conjunction with the direct effects of placental sequestration. Reticulocytosis occurs in some populations during pregnancy and may contribute to an increased risk of P. vivax (Traill, 1975). Taken together, current data show that interactions between $P$. vivax and placental receptors are rare in contrast to the common interaction of $P$. falciparum ligands with placental receptors which largely explains the reduced magnitude of negative outcomes in $P$. vivax infections in pregnancy compared to $P$. falciparum infections.

Plasmodium falciparum and $P$. vivax risk in the postpartum period

How the increased burden and risk of $P$. falciparum and $P$. vivax malaria during pregnancy relates to the risk of malaria in the postpartum period is the focus of increasing research. The World Health Organization defines the postpartum period as beginning $1 \mathrm{~h}$ after the delivery of the placenta and continuing until 6 weeks after the birth of the infant (WHO, 2011). This definition is rarely adhered to in the malaria literature, so for the purpose of this review the postpartum period is defined as the period from delivery to 6 months post-delivery. The majority of postpartum studies have been conducted in Africa and have compared the risk of $P$. falciparum infection postpartum to the risk during pregnancy; with these studies observing a reduced risk of $P$. falciparum infection in the postpartum period (Table 6) (Bray and Anderson, 1979; Watkinson and Rushton, 1983; Steketee et al. 1996; Fievet et al. 1997; Green et al. 2007; Menendez et al. 2008; Serra-Casas et al. 2011). Conversely, the single study that investigated P.falciparum clinical malaria found an increased risk during the 60 days postpartum compared to each trimester of pregnancy (Diagne et al. 2000). The sole study assessing the risk of $P$. vivax and $P$.falciparum infection in postpartum compared to pregnant controls (in Papua New Guinea) found the incidence of $P$. vivax and $P$. falciparum parasitaemia increased from delivery until 4 months postpartum (Brabin et al. 1990) with a greater relative increase in postpartum $P$. vivax incidence than $P$. falciparum incidence. Importantly, chemoprophylaxis was ceased at delivery so this finding may be more reflective of a 'rebound effect' than an indication of the natural course of susceptibility during the postpartum period (Brabin et al. 1990). Overall, the heightened risk of $P$. falciparum seen during pregnancy is typically reduced in the postpartum period, whilst the limited evidence of $P$. vivax risk postpartum compared to pregnancy suggests that the risk is elevated.

To truly evaluate whether malaria risk returns to non-pregnant levels immediately after pregnancy, the postpartum risk needs to be compared to nonpregnant controls. Two studies in Africa (Senegal and Gabon) found an increased risk of P. falciparum infection relative to non-pregnant women (Diagne et al. 2000; Ramharter et al. 2005) (Table 6). Both studies also found a greater increase in the risk of clinical malaria relative to the risk of Plasmodium spp. infection indicating that the postpartum state is more susceptible to clinical malaria than the non-pregnant state independent of an increased risk of infection. Depressed immunity may explain this finding with the Senegal study finding that after 90 days postpartum the risk of clinical P. falciparum malaria returned to the level seen prior to pregnancy, suggesting that the responsible factor for altered postpartum risk returns to normal after 3 months (Diagne et al. 2000). In contrast to African findings, a recent study on the ThaiMyanmar border found that postpartum women had decreased risk of $P$. falciparum episodes than age and location matched non-pregnant controls, whilst there was an increased risk of $P$. vivax episodes in postpartum women compared to 
Table 6. Risk of $P$. vivax and $P$. falciparum in the postpartum period

\begin{tabular}{|c|c|c|c|c|c|c|}
\hline Study & Country & $\begin{array}{l}\text { Postpartum } \\
\text { period }\end{array}$ & $\begin{array}{l}\text { Plasmodium } \\
\text { vivax }\end{array}$ & $\begin{array}{l}\text { Magnitude } \\
(95 \% \text { CI })\end{array}$ & $\begin{array}{l}\text { Plasmodium } \\
\text { falciparum }\end{array}$ & Magnitude (95\% CI) \\
\hline \multicolumn{7}{|c|}{ Risk/odds of infection compared to pregnancy } \\
\hline $\begin{array}{l}\text { Bray and } \\
\text { Anderson } \\
(1979)\end{array}$ & The Gambia & At 1 mo. & $\mathrm{N} / \mathrm{A}$ & $\mathrm{N} / \mathrm{A}$ & Similar ${ }^{\mathrm{a}}$ & $\mathrm{OR}=0 \cdot 81(0 \cdot 41,1 \cdot 53)^{\mathrm{b}}$ \\
\hline $\begin{array}{l}\text { Brabin et al. } \\
\quad(1990)\end{array}$ & $\begin{array}{l}\text { Papua New } \\
\text { Guinea }\end{array}$ & $\begin{array}{l}\text { Across } \\
4 \text { mos. }\end{array}$ & Increased $^{\mathrm{a}}$ & $\begin{array}{l}\operatorname{IRR}=4 \cdot 89 \\
\quad(1 \cdot 92,11 \cdot 59)^{\mathrm{b}}\end{array}$ & Increased $^{\mathrm{a}}$ & $\mathrm{IRR}=1 \cdot 28(0 \cdot 78,2 \cdot 00)^{\mathrm{b}}$ \\
\hline $\begin{array}{l}\text { Steketee et al. } \\
\text { (1996) }\end{array}$ & Malawi & At 2 mos. & $\mathrm{N} / \mathrm{A}$ & N/A & Similar ${ }^{\mathrm{a}}$ & $\mathrm{OR}=0 \cdot 80(0 \cdot 72,0 \cdot 88)^{\mathrm{b}}$ \\
\hline $\begin{array}{l}\text { Fievet et al. } \\
\quad(1997)\end{array}$ & Cameroon & At 6 mos. & $\mathrm{N} / \mathrm{A}$ & $\mathrm{N} / \mathrm{A}$ & Decreased $^{\mathrm{a}, \mathrm{c}}$ & $\mathrm{OR}=0 \cdot 19(0 \cdot 05,0 \cdot 68)^{\mathrm{b}}$ \\
\hline $\begin{array}{l}\text { Diagne } \text { et al. } \\
\quad(2000)\end{array}$ & Senegal & $\begin{array}{l}\text { Across } \\
2 \text { mos. }\end{array}$ & N/A & $\mathrm{N} / \mathrm{A}$ & Increased $^{\mathrm{a}, \mathrm{d}}$ & $\mathrm{IRR}=1 \cdot 75(0 \cdot 75,3 \cdot 76)^{\mathrm{b}}$ \\
\hline $\begin{array}{l}\text { Green } \text { et al. } \\
\quad(2007)\end{array}$ & Kenya & At 2 mos. & $\mathrm{N} / \mathrm{A}$ & $\mathrm{N} / \mathrm{A}$ & Decreased $^{\mathrm{a}}$ & $\mathrm{OR}=0 \cdot 20(0 \cdot 00,1 \cdot 80)^{\mathrm{b}}$ \\
\hline $\begin{array}{l}\text { Menendez } \\
\quad \text { et al. }(2008)\end{array}$ & Mozambique & At 2 mos. & $\mathrm{N} / \mathrm{A}$ & $\mathrm{N} / \mathrm{A}$ & Decreased $^{\mathrm{a}}$ & $\mathrm{OR}=0 \cdot 36(0 \cdot 22,0 \cdot 58)^{\mathrm{b}}$ \\
\hline $\begin{array}{l}\text { Serra-Casas } \\
\quad \text { et al. }(2011)\end{array}$ & Mozambique & At 2 mos. & $\mathrm{N} / \mathrm{A}$ & $\mathrm{N} / \mathrm{A}$ & Decreased $^{\mathrm{e}}$ & $\mathrm{OR}=0 \cdot 35(0 \cdot 19,0 \cdot 61)$ \\
\hline \multicolumn{7}{|c|}{ Risk/odds of clinical malaria compared to pregnancy } \\
\hline $\begin{array}{l}\text { Diagne et al. } \\
\quad(2000)\end{array}$ & Senegal & $\begin{array}{l}\text { Across } \\
2 \text { mos. }\end{array}$ & N/A & $\mathrm{N} / \mathrm{A}$ & Increased $^{f}$ & $\operatorname{IRR}=1.98(0 \cdot 84,4 \cdot 36)^{b}$ \\
\hline \multicolumn{7}{|c|}{ Risk/odds of infection compared to non-pregnant women } \\
\hline $\begin{array}{l}\text { Diagne } \text { et al. } \\
\quad(2000)\end{array}$ & Senegal & $\begin{array}{l}\text { Across } \\
2 \text { mos. }\end{array}$ & $\mathrm{N} / \mathrm{A}$ & $\mathrm{N} / \mathrm{A}$ & Increased $^{\mathrm{a}, \mathrm{d}}$ & $\mathrm{RR}=1 \cdot 8(1 \cdot 1,2 \cdot 7)^{\mathrm{g}}$ \\
\hline $\begin{array}{l}\text { Ramharter } \\
\text { et al. }(2005)\end{array}$ & Gabon & $\begin{array}{l}\text { Across } \\
2 \cdot 5 \mathrm{mos} .\end{array}$ & $\mathrm{N} / \mathrm{A}$ & $\mathrm{N} / \mathrm{A}$ & Increased $^{\mathrm{a}}$ & $\mathrm{IRR}=2 \cdot 7(1 \cdot 0,8 \cdot 2)$ \\
\hline $\begin{array}{l}\text { Boel et al. } \\
\quad(2013)\end{array}$ & Thailand & $\begin{array}{l}\text { Across } \\
3 \text { mos. }\end{array}$ & Increased $^{\mathrm{a}}$ & $\begin{array}{l}\mathrm{HR}=1 \cdot 34 \\
(1 \cdot 05,1 \cdot 72)\end{array}$ & Decreased $^{\mathrm{a}}$ & $\mathrm{HR}=0.39(0 \cdot 21,0.72)$ \\
\hline \multicolumn{7}{|c|}{ Risk/odds of clinical malaria compared to non-pregnant women } \\
\hline $\begin{array}{l}\text { Diagne et al. } \\
\quad(2000)\end{array}$ & Senegal & $\begin{array}{l}\text { Across } \\
2 \text { mos. }\end{array}$ & $\mathrm{N} / \mathrm{A}$ & $\mathrm{N} / \mathrm{A}$ & Increased $^{f}$ & $\mathrm{RR}=4 \cdot 1(1 \cdot 8,9 \cdot 5)^{\mathrm{g}}$ \\
\hline $\begin{array}{l}\text { Ramharter } \\
\text { et al. }(2005)\end{array}$ & Gabon & $\begin{array}{l}\text { Across } \\
2.5 \mathrm{mos} .\end{array}$ & N/A & $\mathrm{N} / \mathrm{A}$ & Increased $^{\text {h }}$ & $\operatorname{IRR}=9 \cdot 8(1 \cdot 4,420 \cdot 0)$ \\
\hline
\end{tabular}

NB - ratios within $0 \cdot 2$ of 1 were considered similar to 1 . All measures of association are unadjusted unless otherwise specified.

Abbreviations: mos., months; LM, light microscopy; OR, odds ratio; IRR, incidence rate ratio; RR, risk ratio; HR, hazard ratio.

a Detected by light microscopy.

b Calculated from data in the paper.

c Study restricted to primigravid women only.

d Asymptomatic infection.

e Detected by PCR.

${ }^{\mathrm{f}}$ Clinical malaria defined as any case of fever or fever-related symptoms associated with a ratio of parasites to leucocytes that exceeds a pyrogenic threshold.

$\mathrm{g}$ Adjusted for exposure, parity, duration of residence in village and effects within study subjects.

h Clinical malaria defined as asexual P. falciparum parasitemia with $>100$ parasites $\mu \mathrm{L}^{-1}$ of blood, fever (current or within the previous $24 \mathrm{~h}$ ), or presence of other symptoms associated with malaria.

non-pregnant controls (Boel et al. 2013). Further research into postpartum risk of malaria will help address the current conflicting evidence of the risk of malaria in the postpartum period.

It has been suggested that the differential risk of malaria in the postpartum period may be due to immunological changes that occur during pregnancy and gradually return to 'normal' in the postpartum period (Diagne et al. 2000; Ramharter et al. 2005). Immunological changes during pregnancy include changes in cell-mediated and humoral immunity (Jamieson et al. 2006; Robinson and Klein, 2012), which would presumably differentially affect susceptibility to $P$. falciparum and $P$. vivax due to underlying species differences in immunopathology.

\section{Immunity to P. falciparum and P. vivax in pregnancy}

A variety of immunological changes occur during pregnancy, with changes in the nature of cytokine responses, a general suppression of cell-mediated immunity and increased humoral immunity (reviewed in Jamieson et al. 2006; Robinson and Klein, 2012). This shift is believed to reduce the 
chance of foetal rejection and increase the maternal transfer of antibodies to the foetus. These broader immunological changes are also likely to contribute to an altered susceptibility to both Plasmodium spp. during pregnancy in addition to the availability of the placenta as a sequestration site.

The broadly suppressed cell-mediated immunological state that exists during pregnancy should dampen the effectiveness of T cells on both $P$. falciparum and $P$. vivax. However, few studies have investigated the impact of an altered cell-mediated response on Plasmodium spp. infection during pregnancy. CD8 T cell levels are higher in the inflammatory infiltrate in chronically $P$. falciparum infected placentas compared to uninfected placentae, past infections, acute infections and placentae from non-exposed women (Ordi et al. 2001). This observation was supported by another study which found greater frequencies of CD8 $\mathrm{T}$ cells producing IFN-alpha and TNF-alpha in P. falciparum infected placentae compared to uninfected placentae (Diouf et al. 2007). Less is known about the role of T cells at the placenta during $P$. vivax infections. An increased presence of mononuclear cells in the placenta was detected in instances of $P$. vivax and $P$. falciparum infections compared to no infection, with similar numbers of mononuclear cells in $P$. vivax and $P$. falciparum infections (Souza et al. 2013).

Another important impact an altered cellmediated immune response may have in pregnancy is an altered ability to control liver stage infection and $P$. vivax relapse. Though direct human evidence is lacking, cell-mediated immunity is thought to be particularly important for pre-erythrocytic immunity on the basis of animal models (reviewed in Doll and Harty, 2014). However, what constitutes an adequate immune response against clinical relapses of $P$. vivax is unknown as is the risk of relapses during the altered immunological state of pregnancy.

The humoral immune response is a crucial component of naturally acquired immunity and antibody responses to both $P$. falciparum and $P$. vivax antigens are important biomarkers of exposure and protective immunity in meta-analyses of non-pregnant populations (Fowkes et al. 2010; Cutts et al. 2014). Numerous studies have demonstrated the important role of anti-PfVAR2CSA humoral immunity in $P$. falciparum infections during pregnancy (reviewed in Duffy, 2007; Hviid and Salanti, 2007; Rogerson, 2010; Ataide et al. 2013). Antibodies reactive against recombinant PfVAR2CSA, and to the surface of erythrocytes infected with $P$. falciparum placental isolates and $P$. falciparum lines selected by their adhesion to CSA increase with gravidity (reviewed in Ataide et al. 2013), indicating that immunity to PfVAR2CSA is acquired or boosted progressively with successive pregnancies, and is associated with parasite clearance and reduced odds of placental infection (Guitard et al. 2008; Feng et al. 2009; Tutterrow et al. 2012a, b). There is currently no complementary evidence for $P$. vivax. The risk of $P$. vivax also tends to decline with gravidity (Table 4), rendering the existence of $P$. vivax antigens that are upregulated in pregnancy and important as immune targets a viable hypothesis. However, in the absence of pregnancy-specific $P$. vivax isolates or antigens, the gravidity effect may also be explained by a broader acquisition and boosting of immunity towards $P v$-IEs and merozoite antigens during exposure to $P$. vivax during pregnancy or merely a reflection of immune acquisition with age. Additional mechanisms that influence susceptibility to both species during pregnancies are increased cortisol concentrations (Vleugels et al. 1989; Bouyou-Akotet et al. 2005) and reduced NK cell activity (Bouyou-Akotet et al. 2004) particularly in primigravid pregnancies.

There is little data available on antibodies to merozoite antigens during pregnancy (including orthologues expressed in both P. falciparum and $P$. vivax, e.g. AMA1, MSP1 19 ). Pregnant women in endemic settings have typically acquired protective immunity to these antigens during childhood; this immunity would likely contribute to a protective effect in pregnancy by reducing parasitaemia, which would have a knock-on protective effect on the burden of placental infection. Evidence to support this is limited, however some studies have found $a d$ hoc associations with particular merozoite antigens (e.g. PfMSP1-19 and PfAMA-1) with improved birth outcomes in women exposed to $P$. falciparum (Taylor et al. 2004; Mayor et al. 2013). Results must be interpreted with caution, given the lack of similar associations with other non-pregnancy specific antigens in the same studies (PfCSP, PfLSA1 PfRESA, PfDBL $\gamma, \quad$ PfDBL $\alpha, \quad$ PfMSP1-19, PfAMA1 PfEBA175). Furthermore, P. falciparum merozoite responses (and $P$. vivax responses in coendemic areas) are often highly correlated with PfVAR2CSA (Fowkes et al. 2012) so associations observed can serve as a proxy for higher levels of other protective responses.

Alternatively, in the absence of $P$. vivax-specific mechanisms, the gravidity effect could be indirect. It has been hypothesized that relapses of $P$. vivax infections are triggered by fever, notably by other malaria infections (reviewed in Shanks and White, 2013). If this were the case then one would expect $P$. falciparum erythrocytic immunity (both cellmediated and humoral), to indirectly protect against $P$. vivax relapse by protecting against febrile symptoms. This indirect mechanism could explain the decreased risk of $P$. vivax with increasing gravidity in co-endemic regions in the absence of more direct immunological mechanisms.

Cross-species immunity also provides an alternative explanation for the gravidity effect of $P$. vivax. 
There is little reliable human data on cross-species immunity. An experimental infection of a non-pregnant individual with $P$. vivax showed that antibodies induced by $P$. vivax, are capable of recognizing $P$. falciparum schizont extract and may be able to inhibit $P$. falciparum growth in vitro (Nagao et al. 2008). How this translates vice versa or in pregnancy is unknown but may explain the interaction in disease severity between the two species in Thailand where $P$. vivax infection reduced the severity and number of $P$. falciparum episodes during pregnancy (Luxemburger et al. 1997; Nosten et al. 1999). Evidence also suggests that high-density blood stage infections may be able to inhibit liver stage infections through an increase in hepcidin levels (reviewed in Portugal et al. 2011). Mechanisms of Plasmodium species-transcending immunity are poorly defined in humans and require further elucidation to determine their role in pregnancy and postpartum.

There is a relatively scarce amount of literature regarding the role of non- $\operatorname{IgG}$ antibodies in $P$. falciparum and $P$. vivax infection during pregnancy and postpartum which is not surprising given that $\mathrm{IgG}$ is considered to be the key immunoglobulin for naturally acquired immunity against malaria (Doolan et al. 2009). IgM is typically observed in the primary response to infection and numerous $P$. falciparum and $P$. vivax antigens elicit IgM responses (Cutts et al. 2014). IgM has been shown to bind non-specifically to PfVAR2CSA a feature which may have evolved as an immune evasion mechanism (Creasey et al. 2003; Elliott et al. 2005; Rasti et al. 2006; Semblat et al. 2006; Barfod et al. 2011). The binding of IgM to PfVAR2CSA has been shown to interfere with specific $\mathrm{IgG}$ recognition and opsonic phagocytosis of IEs infected with pregnancy-specific isolates ((Barfod et al. 2011) but not other non-pregnancy specific PfEMP-1s (Stevenson et al. 2014). IgM has also been implicated in rosetting and strengthening $P f$-IE erythrocyte interactions (Stevenson $e t$ al. 2014) however rosetting is rare in P. falciparum placental isolates (Maubert et al. 1998; Rogerson et al. 2000). There is currently no data on the role of IgM in $P$. vivax rosetting. Further investigation of the role of $\operatorname{IgM}$ in $P$. falciparum and $P$. vivax infections is warranted.

The functional roles $\operatorname{IgG}$ antibodies require for protection against $P$. falciparum and $P$. vivax infection are fairly poorly defined. The predominant isotypes found against $P$. falciparum placental isolates are $\mathrm{IgG} 1$ and $\mathrm{IgG} 3$, the dominant isotypes against most malarial antigens (Elliott et al. 2005; Megnekou et al. 2005; Stanisic et al. 2009; Richards et al. 2010), which can function through adhesion-inhibition/invasion-inhibition, phagocytosis, antibody-dependent cell-mediated cytotoxicity and/or complement fixation. Anti-PfVAR2CSA
IgG can inhibit adhesion by interfering with the binding of $P f$-IEs and CSA or recombinant PfVAR2CSA to CSA (Ricke et al. 2000; Barfod et al. 2010; Khunrae et al. 2010). Opsonic phagocytosis against CSA-binding parasite isolates have been identified in sera from pregnant women (Keen et al. 2007; Tippett et al. 2007; Feng et al. 2009; Ataide et al. 2010, 2011; Barfod et al. 2010). There is little information at present on the contribution of anti-PfVAR2CSA IgG to antibodymediated complement activity, with some indications that excessive innate complement binding is detrimental (Conroy et al. 2009, 2013; Khattab et al. 2013). Antibody-mediated immune functions against a range of $P$. falciparum targets are present during pregnancy (Teo et al. 2014), but whether altered immunology during pregnancy alters their magnitude as compared to non-pregnant individuals is unknown. Studies on $P v$-IE are severely hindered by the inability to culture $P$. vivax long-term in vivo.

In non-pregnant populations, clinical immunity is thought to develop more rapidly to $P$. vivax than $P$. falciparum as indicated from parasitological data from syphilis malariotherapy patients (Collins and Jeffery, 1999a; Collins et al. 2004) and from malaria endemic areas whereby the prevalence of $P$. vivax infection and clinical episodes peaks at younger ages compared to $P$. falciparum (Maitland et al. 1996; Smith et al. 2001; Mueller et al. 2009; Lin et al. 2010). It is hypothesized that this is due to a reduced immune threshold required to achieve protection against $P$. vivax compared to $P$. falciparum or the ability of $P$. vivax to relapse giving rise to a higher molecular force of infection (Koepfli et al. 2013). Species-specific differences in the rate of immune acquisition have yet to be reconciled in pregnancy but longitudinal studies show that antibody responses to both $P$. falciparum and $P$. vivax antigens during pregnancy are similarly dynamic in response to species-specific Plasmodium spp. exposure (Aitken et al. 2010; Fowkes et al. 2012; Ampomah et al. 2014b), lending support to the notion that regular exposure is required to maintain malarial immunity. Interestingly, a recent longitudinal study of antibodies in pregnancy found that antibodies to P. vivax (PvAMA1) were not boosted with successive infections in pregnancy, in contrast with $P$. falciparum antibodies which were boosted with each exposure (including the homologue PfAMA1) (Fowkes et al. 2012). This may indicate a difference in immunological memory or recall response between the two species or the much lower parasitaemia densities in $P$. vivax infections are less efficient in boosting responses. The implications of this lack of boosting for immunity and increased risk of $P$. vivax in pregnancy and the postpartum period (observed in the same study area) are unknown and further studies are necessary. Furthermore an understanding of antibody dynamics 
Table 7. Epidemiological observations of P. falciparum and $P$. vivax during pregnancy and postpartum and proposed mechanisms

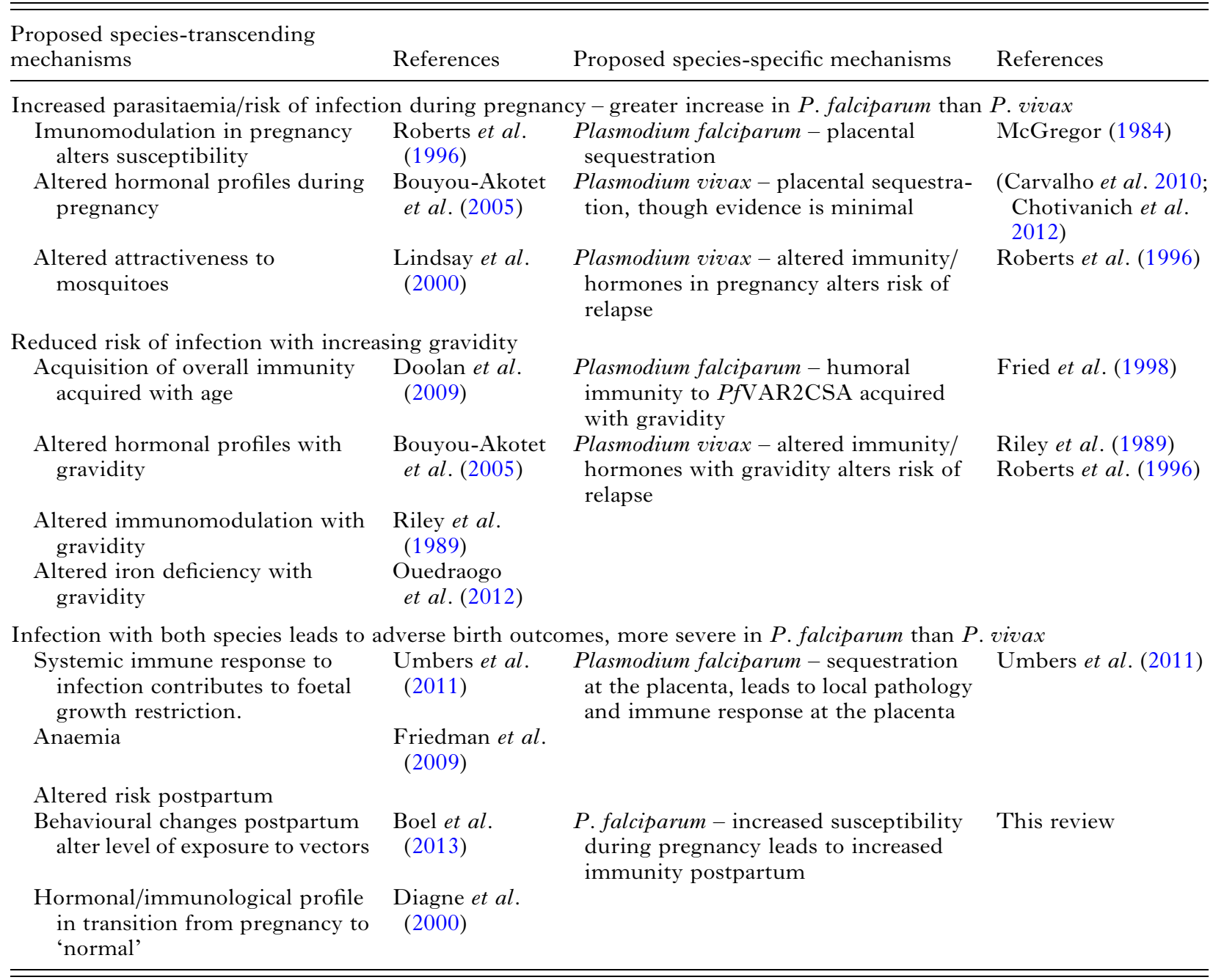

postpartum would help elucidate how pregnancyfavoured antibodies are maintained in between pregnancies with apparent limited exposure to pregnancy-favoured antigens.

\section{Antibody responses postpartum and between pregnancies}

The strong link between gravidity and PfVAR2CSA antibodies suggests that antibody responses and immune memory are maintained between pregnancies and postpartum when exposure to PfVAR2CSA is low. This is at odds with the paradigm that frequent exposure is required to develop a long lasting antibody response to malaria and that, in the absence of repeated exposure, immunity is short lived (i.e. weeks) (Kinyanjui et al. 2003; Langhorne et al. 2008).

Antibodies are secreted by plasma cells, which can be either short-lived or long-lived (Manz et al. 2005). Mathematical modelling has demonstrated that separate populations of long and short lived cells can describe the rapid decay of antibodies observed immediately following exposure and the long-lived maintenance of a lower level of antibodies in African children (White et al. 2014). This is reflected in studies that have investigated antibody longevity. Estimates in individuals' shortly after a drug treated acute episode of malaria typically find short $P$. vivax and $P$. falciparum antibody half-lives (6 to 52 days) (Soares et al. 1999; Kinyanjui et al. 2007) whereas studies investigating long-term decay of antibodies in uninfected individuals have estimated longer $P$. vivax and $P$. falciparum antibody half-lives in excess of 5 years (Drakeley et al. 2005; Wipasa et al. 2010). Additionally, antibodies have been detected in individuals who have not been exposed to either species in over 5 years (Luby et al. 1967; Druilhe et al. 1986; Braga et al. 1998; Wipasa et al. 2010; Moncunill et al. 2013; Ndungu et al. 2013).

Little is known about antibody longevity in pregnancy and postpartum. A study in a low 
transmission co-endemic area of Thailand found that $P$. vivax and $P$. falciparum merozoite antibody response half-lives calculated during pregnancy were shorter than that calculated for PfVAR2CSA responses and was longer in those who had been exposed $(0 \cdot 8-7 \cdot 6$ years for merozoite antigens $v s$ 57.6-142 years for VAR2CSA (Fowkes et al. 2012)). While these estimates should not be directly extrapolated from pregnancy into the postpartum period, recent evidence from cohorts of pregnant and postpartum women provide further evidence for long-term antibody maintenance postpartum. A study in Mozambique found that women 1-2 months postpartum had a median level of antibodies against the surface of a placental parasite line (CS2) comparable $(3 \cdot 3 \%$ higher $)$ to women at delivery (Mayor et al. 2012b). A study in Malawi found that at 6 months postpartum $72 \cdot 3 \%$ of women were still seropositive for antibodies to CS2 surface antigens (Aitken et al. 2010). More than 40\% of women in Ghana who had not been pregnant in 1-6 years remained seropositive to PfVAR2CSA suggesting that there is some level of antibody response maintenance in the relative absence of exposure (Ampomah et al. 2014a, b). Importantly they also demonstrated that the level of PfVAR2CSA specific IgG-secreting B cells did not depend on time since last pregnancy or number of pregnancies suggesting that PfVAR2CSA B cell memory is stably maintained in the absence of exposure (Ampomah et al. 2014a).

Explanations for an apparent increased longevity of PfVAR2CSA responses are unclear, but could relate to a large sequestered parasite load providing a strong and sustained antigenic stimulus or be reflective of boosting as a result of undetected placental infection during pregnancy, or the greater immune longevity that appears to occur in adults. It is thought that there is limited or infrequent exposure to PfVAR2CSA prior to the first pregnancy, in contrast to most malarial antigens, which are generally encountered throughout life. However, studies have shown that antibodies to PfVAR2CSA can be acquired in childhood (Beeson et al. 2007). This would influence subsequent response to PfVAR2CSA in pregnancy such that antibody levels may be boosted more rapidly upon re-exposure and be better maintained. Younger individuals tend to have shorter half-lives than older individuals (Taylor et al. 1996; Akpogheneta et al. 2008) and the age of primary exposure to an antigen may affect the longevity of immune responses to that antigen. The detection of PfVAR2CSA antibodies in women who have not been pregnant in years and the observed persistence of PfVAR2CSA specific IgG-secreting B cells supports the hypothesis that PfVAR2CSA antibodies acquired in earlier pregnancies are maintained to protect subsequent pregnancies against
P. falciparum. However, further longitudinal studies of women followed after pregnancy are required to assess this.

Whether there are $P$. vivax antigens that are specifically upregulated in pregnancy and whether antibodies against P.vivax are maintained postpartum and throughout pregnancies is unknown. Furthermore, the extent to which the immunological changes that occur during pregnancy and postpartum influence the risk of $P$. vivax relapse is unclear. If cell-mediated immunity is important in controlling liver infection, as it is in mouse models (reviewed in Doll and Harty, 2014), then the dampening of cell-mediated immunity would have a greater impact on $P$. vivax than $P$. falciparum due to the former parasites relatively longer period of residence in the liver. More immunological research is needed to further understand how immunity relates to the differential risk of $P$. falciparum and $P$. vivax postpartum.

\section{Box I. Research priorities}

- Further epidemiological studies on the risk of $P$. vivax by pregnancy status and gravidity in different populations.

- Elucidate the mechanisms by which $P$. vivax infection during pregnancy contributes to negative maternal and infant outcomes.

- Quantify the clinical relevance of putative in vivo $P$. vivax binding to the placenta.

- Conduct longitudinal studies in pregnant women that incorporate humoral, cellular and functional immunity against both $P$. vivax and $P$. falciparum to quantify their relative contributions towards protection against infection and its course.

- Determine the risk of $P$. vivax and $P$. falciparum postpartum in different settings, ideally with both pregnant and non-pregnant comparison groups.

- Elucidate the immunological mechanisms of altered risk postpartum.

- Investigate the modulating effect of pregnancy on cell-mediated immunity in a malaria context.

- Discover the mechanisms that underpin the cause of $P$. vivax relapse.

- Identify immune correlates of protection against $P$. vivax relapse.

- Determine the contribution of crossspecies immunity in naturally exposed human populations. 


\section{FUTURE DIRECTIONS}

Immunological evidence has helped provide a convincing explanation for the unique epidemiology of $P$. falciparum in pregnancy. Many questions remain to be answered in relation to $P$. vivax during pregnancy and the risk of both species postpartum (Table 7 and Box 1). Currently the availability of both immunological and epidemiological evidence pertaining to $P$. vivax in pregnancy is limited and inconsistent. A more comprehensive understanding of the epidemiology of $P$. vivax in pregnancy will act as a primer for future studies on the immunology of $P$. vivax in pregnancy. Ideally, comprehensive longitudinal studies that incorporate measurements of multiple immunological mechanisms would be able to assess the relative contribution of each of these functions towards protection and the observed epidemiology. Whether delivery marks the end of a period of increased risk of malaria is debatable. The epidemiology of the postpartum period remains unclear, with the few studies conducted providing conflicting results. Further epidemiological studies are needed to explore the differential risk of $P$. falciparum and $P$. vivax in the postpartum period, preferably in tandem with immunological studies, which may be able to explain the mechanisms underlying the epidemiology.

\section{ACKNOWLEDGEMENTS}

ARDM is supported by an Australian Postgraduate Award, FJIF is supported by a Future Fellowship from the Australian Research Council, JGB is supported by a NHMRC Senior Research Fellowship. The Burnet Institute is supported by the NHMRC Independent Research Institutes Infrastructure Support Scheme and the Victorian State Government Operational Infrastructure Support scheme.

\section{REFERENCES}

Aitken, E. H., Mbewe, B., Luntamo, M., Maleta, K., Kulmala, T., Friso, M.-J., Fowkes, F. J. I., Beeson, J. G., Ashorn, P. and Rogerson, S. J. (2010). Antibodies to chondroitin sulfate a-binding infected erythrocytes: dynamics and protection during pregnancy in women receiving intermittent preventive Treatment. Fournal of Infectious Diseases 201, 1316-1325.

Akpogheneta, O. J., Duah, N. O., Tetteh, K. K., Dunyo, S., Lanar, D. E., Pinder, M. and Conway, D. J. (2008). Duration of naturally acquired antibody responses to blood-stage Plasmodium falciparum is age dependent and antigen specific. Infection and Immunity 76, 1748-1755.

Almeida, L. B., Barbosa, M. and Martinez-Espinosa, F. E. (2010). Malaria among women aged 10 to 49 years, according to SIVEP-Malaria, Manaus, State of Amazonas, 2003-2006. Revista da Sociedade Brasileira de Medicina Tropical 43, 304-308.

Ampomah, P., Stevenson, L., Ofori, M. F., Barfod, L. and Hviid, L. $(2014 a)$. B-Cell responses to pregnancy-restricted and -unrestricted Plasmodium falciparum erythrocyte membrane protein 1 antigens in Ghanaian women naturally exposed to malaria parasites. Infection and Immunity 82, 1860-1871.

Ampomah, P., Stevenson, L., Ofori, M. F., Barfod, L. and Hviid, L. (2014b). Kinetics of B cell responses to Plasmodium falciparum erythrocyte membrane Protein 1 in ghanaian women naturally exposed to malaria parasites. Fournal of Immunology 192, 5236-5244. doi: 10.4049/jimmunol.1400325. Anstey, N. M., Douglas, N. M., Poespoprodjo, J. R. and Price, R. N. (2012). Plasmodium vivax: clinical spectrum, risk factors and pathogenesis. Advances in Parasitology 80, 151-201.

Appleyard, B., Tuni, M., Cheng, Q., Chen, N., Bryan, J. and McCarthy, J. S. (2008). Malaria in pregnancy in the Solomon islands: barriers to prevention and control. American Fournal of Tropical Medicine and Hygiene 78, 449-454

Arango, E. M., Samuel, R., Agudelo, O. M., Carmona-Fonseca, J., Maestre, A. and Yanow, S. K. (2013). Molecular detection of malaria at delivery reveals a high frequency of submicroscopic infections and associated placental damage in pregnant women from northwest Colombia. American Fournal of Tropical Medicine and Hygiene 89, 178-183. Ataide, R., Hasang, W., Wilson, D. W., Beeson, J. G., Mwapasa, V., Molyneux, M. E., Meshnick, S. R. and Rogerson, S. J. (2010). Using an improved phagocytosis assay to evaluate the effect of HIV on specific antibodies to pregnancy-associated malaria. PLoS ONE 5, e10807.

Ataide, R., Mwapasa, V., Molyneux, M.E., Meshnick, S. R. and Rogerson, S. J. (2011). Antibodies that induce phagocytosis of malaria infected erythrocytes: effect of HIV infection and correlation with clinical outcomes. PLoS ONE 6, e22491.

Ataide, R., Mayor, A. and Rogerson, S. J. (2013). Malaria, primigravidae, and antibodies: knowledge gained and future perspectives. Trends in Parasitology 30, 85-94. doi: 10.1016/j.pt.2013.12.007.

Barcus, M. J., Basri, H., Picarima, H., Manyakori, C., Sekartuti, Elyazar, I., Bangs, M. J., Maguire, J.D. and Baird, J. K. (2007). Demographic risk factors for severe and fatal vivax and falciparum malaria among hospital admissions in northeastern Indonesian Papua. American Fournal of Tropical Medicine and Hygiene 77, 984-991.

Barfod, L., Dobrilovic, T., Magistrado, P., Khunrae, P., Viwami, F., Bruun, J., Dahlback, M., Bernasconi, N. L., Fried, M., John, D., Duffy, P. E., Salanti, A., Lanzavecchia, A., Lim, C., Ndam, N.T., Higgins, M. K. and Hviid, L. (2010). Chondroitin sulfate A-adhering Plasmodium falciparum-infected erythrocytes express functionally important antibody epitopes shared by multiple variants. Fournal of Immunology 185, 7553-7561.

Barfod, L., Dalgaard, M. B., Pleman, S. T., Ofori, M. F., Pleass, R. J. and Hviid, L. (2011). Evasion of immunity to Plasmodium falciparum malaria by IgM masking of protective IgG epitopes in infected erythrocyte surface-exposed PfEMP1. Proceedings of the National Academy of Sciences of the United States of America 108, 12485-12490.

Barnett, S., Nair, N., Tripathy, P., Borghi, J., Rath, S. and Costello, A. (2008). A prospective key informant surveillance system to measure maternal mortality - findings from indigenous populations in Jharkhand and Orissa, India. BMC Pregnancy Childbirth 8, 6.

Beeson, J. G. and Brown, G. V. (2004). Plasmodium falciparum-infected erythrocytes demonstrate dual specificity for adhesion to hyaluronic acid and chondroitin sulfate A and have distinct adhesive properties. Fournal of Infectious Diseases 189, 169-179.

Beeson, J. G., Brown, G. V., Molyneux, M. E., Mhango, C., Dzinjalamala, F. and Rogerson, S. J. (1999). Plasmodium falciparum isolates from infected pregnant women and children are associated with distinct adhesive and antigenic properties. Fournal of Infectious Diseases $\mathbf{1 8 0}$, 464-472.

Beeson, J. G., Rogerson, S. J., Cooke, B. M., Reeder, J. C., Chai, W., Lawson, A. M., Molyneux, M. E. and Brown, G. V. (2000). Adhesion of Plasmodium falciparum-infected erythrocytes to hyaluronic acid in placental malaria. Nature Medicine 6, 86-90.

Beeson, J. G., Amin, N., Kanjala, M. and Rogerson, S. J. (2002). Selective accumulation of mature asexual stages of Plasmodium falciparum-infected erythrocytes in the placenta. Infection and Immunity $\mathbf{7 0}$, 5412-5415.

Beeson, J. G., Ndungu, F., Persson, K. E., Chesson, J. M., Kelly, G. L., Uyoga, S., Hallamore, S. L., Williams, T. N., Reeder, J.C., Brown, G. V. and Marsh, K. (2007). Antibodies among men and children to placental-binding Plasmodium falciparum-infected erythrocytes that express var2csa. American Fournal of Tropical Medicine and Hygiene 77. 22-28.

Boel, M. E., Rijken, M. J., Brabin, B. J., Nosten, F. and McGready, R. (2012). The epidemiology of postpartum malaria: a systematic review. Malaria fournal 11, 114

Boel, M. E., Rijken, M. J., Leenstra, T., Pyae Phyo, A., Pimanpanarak, M., Keereecharoen, N. L., Proux, S., Laochan, N., Imwong, M., Singhasivanon, P., White, N. J., McGready, R. and Nosten, F. H. (2013). Malaria in the post-partum period; a prospective cohort study. PLoS ONE 8, e57890. 
Bouyou-Akotet, M. K., Issifou, S., Meye, J. F., Kombila, M., NgouMilama, E., Luty, A. J., Kremsner, P. G. and Mavoungou, E. (2004). Depressed natural killer cell cytotoxicity against Plasmodium falciparuminfected erythrocytes during first pregnancies. Clinical Infectious Diseases 38, 342-347.

Bouyou-Akotet, M. K., Adegnika, A.A., Agnandji, S. T., NgouMilama, E., Kombila, M., Kremsner, P. G. and Mavoungou, E. (2005). Cortisol and susceptibility to malaria during pregnancy. Microbes and Infection 7, 1217-1223.

Brabin, B. J., Ginny, M., Alpers, M., Brabin, L., Eggelte, T. and Van der Kaay, H. J. (1990). Failure of chloroquine prophylaxis for falciparum malaria in pregnant women in Madang, Papua New Guinea. Annals of Tropical Medicine and Parasitology 84, 1-9.

Braga, E. M., Fontes, C. J. and Krettli, A. U. (1998). Persistence of humoral response against sporozoite and blood-stage malaria antigens 7 years after a brief exposure to Plasmodium vivax. Fournal of Infectious Diseases 177, 1132-1135.

Bray, R. S. and Anderson, M. J. (1979). Falciparum malaria and pregnancy. Transactions of the Royal Society of Tropical Medicine and Hygiene 73, 427-431.

Bulmer, J. N., Rasheed, F. N., Francis, N., Morrison, L. and Greenwood, B. M. (1993). Placental malaria. I. Pathological classification. Histopathology 22, 211-218.

Campbell, C. C., Martinez, J.M. and Collins, W.E. (1980). Seroepidemiological studies of malaria in pregnant women and newborns from coastal El Salvador. American fournal of Tropical Medicine and Hygiene 29, 151-157.

Carmona-Fonseca, J., Arango, E. and Maestre, A. (2013). Placental malaria in Colombia: histopathologic findings in Plasmodium vivax and P. falciparum infections. American Fournal of Tropical Medicine and Hygiene 88, 1093-1101.

Carvalho, B. O., Lopes, S. C., Nogueira, P. A., Orlandi, P.P., Bargieri, D. Y., Blanco, Y. C., Mamoni, R., Leite, J. A., Rodrigues, M.M., Soares, I.S., Oliveira, T.R., Wunderlich, G., Lacerda, M. V., del Portillo, H. A., Araujo, M. O., Russell, B., Suwanarusk, R., Snounou, G., Renia, L. and Costa, F. T. (2010). On the cytoadhesion of Plasmodium vivax-infected erythrocytes. Fournal of Infectious Diseases 202, 638-647.

Chaikitgosiyakul, S., Rijken, M. J., Muehlenbachs, A., Lee, S. J., Chaisri, U., Viriyavejakul, P., Turner, G. D., Pongponratn, E., Nosten, F. and McGready, R. (2014). A morphometric and histological study of placental malaria shows significant changes to villous architecture in both Plasmodium falciparum and Plasmodium vivax infection. Malaria Fournal 13, 4.

Chotivanich, K., Udomsangpetch, R., Suwanarusk, R., Pukrittayakamee, S., Wilairatana, P., Beeson, J. G., Day, N. P. and White, N. J. (2012). Plasmodium vivax adherence to placental glycosaminoglycans. PLoS ONE 7, e34509.

Collins, W. E. and Jeffery, G. M. (1999a). A retrospective examination of secondary sporozoite- and trophozoite-induced infections with Plasmodium falciparum: development of parasitologic and clinical immunity following secondary infection. American Fournal of Tropical Medicine and Hygiene 61, 20-35.

Collins, W. E. and Jeffery, G. M. (1999b). A retrospective examination of sporozoite- and trophozoite-induced infections with Plasmodium falciparum in patients previously infected with heterologous species of Plasmodium: effect on development of parasitologic and clinical immunity. American Fournal of Tropical Medicine and Hygiene 61, 36-43.

Collins, W. E., Jeffery, G. M. and Roberts, J. M. (2004). A retrospective examination of reinfection of humans with Plasmodium vivax. American Fournal of Tropical Medicine and Hygiene 70, 642-644.

Conroy, A., Serghides, L., Finney, C., Owino, S. O., Kumar, S. Gowda, D. C., Liles, W. C., Moore, J. M. and Kain, K. C. (2009). C5a enhances dysregulated inflammatory and angiogenic responses to malaria in vitro: potential implications for placental malaria. PLoS ONE 4, e4953. Conroy, A. L., Silver, K. L., Zhong, K., Rennie, M., Ward, P., Sarma, J. V., Molyneux, M. E., Sled, J., Fletcher, J. F., Rogerson, S. and Kain, K. C. (2013). Complement activation and the resulting placental vascular insufficiency drives fetal growth restriction associated with placental malaria. Cell Host and Microbe 13, 215-226.

Creasey, A. M., Staalsoe, T., Raza, A., Arnot, D. E. and Rowe, J. A. (2003). Nonspecific immunoglobulin M binding and chondroitin sulfate A binding are linked phenotypes of Plasmodium falciparum isolates implicated in malaria during pregnancy. Infection and Immunity 71, 4767-4771. Cutts, J. C., Powell, R., Agius, P. A., Beeson, J. G., Simpson, J. A. and Fowkes, F. J. (2014). Immunological markers of Plasmodium vivax exposure and immunity: a systematic review and meta-analysis. $B M C$ Medicine 12, 150.
Dellicour, S., Guerra, C.A., Kuile, F.O.T., Snow, R.W. and Tatem, A. J. (2010). Quantifying the number of pregnancies at risk of malaria in 2007: a demographic study. PLoS Medicine 7, e1000221

Desai, M., ter Kuile, F. O., Nosten, F., McGready, R., Asamoa, K., Brabin, B. and Newman, R. D. (2007). Review: epidemiology and burden of malaria in pregnancy. Lancet Infectious Diseases 7, 93-104. Diagne, N., Rogier, C., Sokhna, C.S., Tall, A., Fontenille, D., Roussilhon, C., Spiegel, A. and Trape, J. F. (2000). Increased susceptibility to malaria during the early postpartum period. New England Fournal of Medicine 343, 598-603.

Diouf, I., Fievet, N., Doucoure, S., Ngom, M., Andrieu, M., Mathieu, J.F., Gaye, A., Thiaw, O. T. and Deloron, P. (2007). IL-12 producing monocytes and IFN-gamma and TNF-alpha producing T-lymphocytes are increased in placentas infected by Plasmodium falciparum. Fournal of Reproductive Immunology 74, 152-162.

Doll, K. L. and Harty, J. T. (2014). Correlates of protective immunity following whole sporozoite vaccination against malaria. Immunologic Research 59, 166-176. doi: 10.1007/s12026-014-8525-0.

Doolan, D. L., Dobano, C. and Baird, J. K. (2009). Acquired immunity to malaria. Clinical Microbiology Reviews 22, 13-36, Table of Contents.

Doumbo, O. K., Thera, M. A., Kone, A. K., Raza, A., Tempest, L. J., Lyke, K. E., Plowe, C. V. and Rowe, J. A. (2009). High levels of Plasmodium falciparum rosetting in all clinical forms of severe malaria in African children. American Yournal of Tropical Medicine and Hygiene 81, 987-993

Drakeley, C. J., Corran, P.H., Coleman, P. G., Tongren, J.E., McDonald, S. L., Carneiro, I., Malima, R., Lusingu, J., Manjurano, A., Nkya, W. M., Lemnge, M. M., Cox, J., Reyburn, H. and Riley, E. M. (2005). Estimating medium- and long-term trends in malaria transmission by using serological markers of malaria exposure. Proceedings of the National Academy of Sciences of the United States of America 102, 5108-5113.

Dreyfuss, M. L., Stoltzfus, R. J., Shrestha, J. B., Pradhan, E. K., LeClerq, S. C., Khatry, S. K., Shrestha, S. R., Katz, J., Albonico, M. and West, K. P., Jr. (2000). Hookworms, malaria and vitamin A deficiency contribute to anemia and iron deficiency among pregnant women in the plains of Nepal. Fournal of Nutrition 130, 2527-2536.

Druilhe, P., Pradier, O., Marc, J.P., Miltgen, F., Mazier, D. and Parent, G. (1986). Levels of antibodies to Plasmodium falciparum sporozoite surface antigens reflect malaria transmission rates and are persistent in the absence of reinfection. Infection and Immunity 53, 393-397.

Duffy, P. E. (2007). Plasmodium in the placenta: parasites, parity, protection, prevention and possibly preeclampsia. Parasitology 134, 1877-1881. Elliott, S. R., Brennan, A. K., Beeson, J. G., Tadesse, E., Molyneux, M. E., Brown, G. V. and Rogerson, S. J. (2005). Placental malaria induces variant-specific antibodies of the cytophilic subtypes immunoglobulin G1 (IgG1) and IgG3 that correlate with adhesion inhibitory activity. Infection and Immunity 73, 5903-5907.

Feng, G., Aitken, E., Yosaatmadja, F., Kalilani, L., Meshnick, S. R., Jaworowski, A., Simpson, J. A. and Rogerson, S. J. (2009). Antibodies to variant surface antigens of Plasmodium falciparum-infected erythrocytes are associated with protection from treatment failure and the development of anemia in pregnancy. Fournal of Infectious Diseases 200, 299-306.

Fievet, N., Cot, M., Ringwald, P., Bickii, J., Dubois, B., Le Hesran, J. Y., Migot, F. and Deloron, P. (1997). Immune response to Plasmodium falciparum antigens in Cameroonian primigravidae: evolution after delivery and during second pregnancy. Clinical and Experimental Immunology 107, 462-467.

Flick, K., Scholander, C., Chen, Q., Fernandez, V., Pouvelle, B., Gysin, J. and Wahlgren, M. (2001). Role of nonimmune IgG bound to PfEMP1 in placental malaria. Science (New York, N.Y.) 293, 2098-2100. Fowkes, F. J., McGready, R., Cross, N. J., Hommel, M., Simpson, J. A., Elliott, S. R., Richards, J. S., Lackovic, K., Viladpai-Nguen, J., Narum, D., Tsuboi, T., Anders, R. F., Nosten, F. and Beeson, J. G. (2012). New insights into acquisition, boosting and longevity of immunity to malaria in pregnant women. Fournal of Infectious Diseases 206, 1612-1621. doi: 10.1093/infdis/jis566.

Fowkes, F. J. I., Richards, J. S., Simpson, J. A. and Beeson, J. G. (2010). The relationship between anti-merozoite antibodies and incidence of Plasmodium falciparum malaria: a systematic review and meta-analysis. PLoS Medicine 7, 1-20.

Fried, M. and Duffy, P. E. (1996). Adherence of Plasmodium falciparum to chondroitin sulfate A in the human Pplacenta. Science 272, 1502-1504.

Fried, M., Nosten, F., Brockman, A., Brabin, B. J. and Duffy, P. E. (1998). Maternal antibodies block malaria. Nature 395, 851-852.

Friedman, J.F., Kurtis, J. D., Kabyemela, E. R., Fried, M. and Duffy, P.E. (2009). The iron trap: iron, malaria and anemia at the mother-child interface. Microbes and Infection 11, 460-466. 
Green, M.D., van Eijk, A. M., van Ter Kuile, F. O., Ayisi, J. G., Parise, M. E., Kager, P.A., Nahlen, B. L., Steketee, R. and Nettey, H. (2007). Pharmacokinetics of sulfadoxine-pyrimethamine in HIV-infected and uninfected pregnant women in Western Kenya. Fournal of Infectious Diseases 196, 1403-1408.

Guitard, J., Cottrell, G., Magnouha, N. M., Salanti, A., Tengfei, L., Sokhna, S., Deloron, P. and Ndam, N. T. (2008). Differential evolution of anti-VAR2CSA-IgG3 in primigravidae and multigravidae pregnant women infected by Plasmodium falciparum. Malaria Fournal 7, 1-6.

Handunnetti, S. M., David, P. H., Perera, K. L. and Mendis, K. N. (1989). Uninfected erythrocytes form "rosettes" around Plasmodium falciparum infected erythrocytes. American Fournal of Tropical Medicine and Hygiene, 40, 115-118.

Hemmer, C. J., Holst, F. G., Kern, P., Chiwakata, C. B., Dietrich, M. and Reisinger, E. C. (2006). Stronger host response per parasitized erythrocyte in Plasmodium vivax or ovale than in Plasmodium falciparum malaria. Tropical Medicine and International Health 11, 817-823.

Hviid, L. and Salanti, A. (2007). VAR2CSA and protective immunity against pregnancy-associated Plasmodium falciparum malaria. Parasitology, 134, 1871-1876.

Ismail, M. R., Ordi, J., Menendez, C., Ventura, P. J., Aponte, J. J., Kahigwa, E., Hirt, R., Cardesa, A. and Alonso, P. L. (2000). Placental pathology in malaria: a histological, immunohistochemical, and quantitative study. Human Pathology 31, 85-93.

Jamieson, D. J., Theiler, R. N. and Rasmussen, S. A. (2006). Emerging infections and pregnancy. Emerging Infectious Diseases 12, 1638-1643.

Keen, J., Serghides, L., Ayi, K., Patel, S. N., Ayisi, J., van Eijk, A., Steketee, R., Udhayakumar, V. and Kain, K. C. (2007). HIV impairs opsonic phagocytic clearance of pregnancy-associated malaria parasites. PLoS Medicine 4, e181

Khattab, A., Kremsner, P. G. and Meri, S. (2013). Complement activation in primiparous women from a malaria endemic area is associated with reduced birthweight. Placenta 34, 162-167.

Khunrae, P., Dahlbäck, M., Nielsen, M. A., Andersen, G., Ditlev, S. B., Resende, M., Pinto, V. V., Theander, T. G., Higgins, M. K. and Salanti, A. (2010). Full-length recombinant Plasmodium falciparum VAR2CSA binds specifically to CSPG and induces potent parasite adhesion-blocking antibodies. Fournal of Molecular Biology 397, 826-834. Kinyanjui, S. M., Bull, P., Newbold, C. I. and Marsh, K. (2003). Kinetics of antibody responses to Plasmodium falciparum-infected erythrocyte variant surface antigens. Fournal of Infectious Diseases 187, $667-674$

Kinyanjui, S. M., Conway, D. J., Lanar, D. E. and Marsh, K. (2007). IgG antibody responses to Plasmodium falciparum merozoite antigens in Kenyan children have a short half-life. Malaria fournal 6, 82.

Koepfli, C., Colborn, K. L., Kiniboro, B., Lin, E., Speed, T. P., Siba, P. M., Felger, I. and Mueller, I. (2013). A high force of plasmodium vivax blood-stage infection drives the rapid acquisition of immunity in papua new guinean children. PLoS Neglected Tropical Diseases 7, e2403.

Krotoski, W. A. (1985). Discovery of the hypnozoite and a new theory of malarial relapse. Transactions of the Royal Society of Tropical Medicine and Hygiene 79, 1-11.

Krotoski, W. A., Collins, W. E., Bray, R. S., Garnham, P. C., Cogswell, F. B., Gwadz, R. W., Killick-Kendrick, R., Wolf, R., Sinden, R., Koontz, L. C. and Stanfill, P.S. (1982). Demonstration of hypnozoites in sporozoite-transmitted Plasmodium vivax infection. American Yournal of Tropical Medicine and Hygiene 31, 1291-1293.

Langhorne, J., Ndungu, F. M., Sponaas, A. M. and Marsh, K. (2008). Immunity to malaria: more questions than answers. Nature Immunology $\mathbf{9}$, 725-732.

Lee, W. C., Malleret, B., Lau, Y. L., Mauduit, M., Fong, M. Y., Cho, J. S., Suwanarusk, R., Zhang, R., Albrecht, L., Costa, F. T., Preiser, P., McGready, R., Renia, L., Nosten, F. and Russell, B. (2014). Glycophorin C (CD236R) mediates vivax malaria parasite rosetting to normocytes. Blood 123, e100-e109.

Lin, E., Kiniboro, B., Gray, L., Dobbie, S., Robinson, L., Laumaea, A., Schopflin, S., Stanisic, D., Betuela, I., BloodZikursh, M., Siba, P., Felger, I., Schofield, L., Zimmerman, P. and Mueller, I. (2010). Differential patterns of infection and disease with $P$. falciparum and $P$. vivax in young Papua New Guinean children. PLoS ONE 5, e9047.

Lindsay, S., Ansell, J., Selman, C., Cox, V., Hamilton, K. and Walraven, G. (2000). Effect of pregnancy on exposure to malaria mosquitoes. Lancet 355, 1972.

Luby, J.P., Collins, W.E. and Kaiser, R.L. (1967). Persistence of malarial antibody. Findings in patients infected during the outbreak of malaria in Lake Vera, California, 1952-1953. American Fournal of Tropical Medicine and Hygiene 16, 255-257.
Luxemburger, C., Thwai, K. L., White, N. J., Webster, H. K., Kyle, D. E., Maelankirri, L., Chongsuphajaisiddhi, T. and Nosten, F. (1996). The epidemiology of malaria in a Karen population on the western border of Thailand. Transactions of the Royal Society of Tropical Medicine and Hygiene 90, 105-111.

Luxemburger, C., Ricci, F., Nosten, F., Raimond, D., Bathet, S. and White, N. J. (1997). The epidemiology of severe malaria in an area of low transmission in Thailand. Transactions of the Royal Society of Tropical Medicine and Hygiene 91, 256-262.

Luxemburger, C., McGready, R., Kham, A., Morison, L., Cho, T., Chongsuphajaisiddhi, T., White, N. J. and Nosten, F. (2001). Effects of malaria during pregnancy on infant mortality in an area of low malaria transmission. American fournal of Epidemiology 154, 459-465.

Machado Filho, A. C., da Costa, E. P., Reis, I. S., Fernandes, E. A., Paim, B. V. and Martinez-Espinosa, F.E. (2014). Effects of vivax malaria acquired before 20 weeks of pregnancy on subsequent changes in fetal growth. American Fournal of Tropical Medicine and Hygiene 90, 371-376.

Maitland, K., Williams, T. N., Bennett, S., Newbold, C. I., Peto, T. E., Viji, J., Timothy, R., Clegg, J. B., Weatherall, D. J. and Bowden, D. K. (1996). The interaction between Plasmodium falciparum and P. vivax in children on Espiritu Santo island, Vanuatu. Transactions of the Royal Society of Tropical Medicine and Hygiene 90, 614-620.

Manz, R. A., Hauser, A. E., Hiepe, F. and Radbruch, A. (2005) Maintenance of serum antibody levels. Annual Review of Immunology 23, 367-386.

Marin-Menendez, A., Bardaji, A., Martinez-Espinosa, F. E., BottoMenezes, C., Lacerda, M. V., Ortiz, J., Cistero, P., Piqueras, M., Felger, I., Mueller, I., Ordi, J., del Portillo, H., Menendez, C., Wahlgren, M. and Mayor, A. (2013). Rosetting in Plasmodium vivax: a cytoadhesion phenotype associated with anaemia. PLoS Neglected Tropical Diseases 7, e2155.

Martinez-Espinosa, F. E., Daniel-Ribeiro, C. T. and Alecrim, W. D. (2004). Malaria during pregnancy in a reference centre from the Brazilian Amazon: unexpected increase in the frequency of Plasmodium falciparum infections. Memorias do Instituto Oswaldo Cruz 99, 19-21.

Maubert, B., Fievet, N., Tami, G., Boudin, C. and Deloron, P. (1998). Plasmodium falciparum-isolates from Cameroonian pregnant women do not rosette. Parasite 5, 281-283.

Mayor, A., Bardaji, A., Felger, I., King, C. L., Cistero, P., Dobano, C., Stanisic, D. I., Siba, P., Wahlgren, M., del Portillo, H., Mueller, I., Menendez, C., Ordi, J. and Rogerson, S. (2012a). Placental infection with Plasmodium vivax: a histopathological and molecular study. Fournal of Infectious Diseases 206, 1904-1910.

Mayor, A., Serra-Casas, E., Rovira-Vallbona, E., Jimenez, A., Quinto, L., Sigauque, B., Dobano, C., Bardaji, A., Alonso, P. L. and Menendez, C. (2012b). Immunoglobulins against the surface of Plasmodium falciparum-infected erythrocytes increase one month after delivery. Malaria fournal 11, 130

Mayor, A., Kumar, U., Bardaji, A., Gupta, P., Jimenez, A., Hamad, A., Sigauque, B., Singh, B., Quinto, L., Kumar, S., Gupta, P. K., Chauhan, V.S., Dobano, C., Alonso, P.L., Menendez, C. and Chitnis, C. E. (2013). Improved pregnancy outcomes in women exposed to malaria with high antibody levels against Plasmodium falciparum. Fournal of Infectious Diseases 207, 1664-1674. doi: 10.1093/ infdis/jit083.

McGready, R., Davison, B. B., Stepniewska, K., Cho, T., Shee, H., Brockman, A., Udomsangpetch, R., Looareesuwan, S., White, N. J., Meshnick, S. R. and Nosten, F. (2004). The effects of Plasmodium falciparum and P. vivax infections on placental histopathology in an area of low malaria transmission. American Fournal of Tropical Medicine and Hygiene 70, 398-407.

McGready, R., Lee, S. J., Wiladphaingern, J., Ashley, E. A., Rijken, M.J., Boel, M., Simpson, J.A., Paw, M. K., Pimanpanarak, M., Mu, O., Singhasivanon, P., White, N. J. and Nosten, F.H. (2012). Adverse effects of falciparum and vivax malaria and the safety of antimalarial treatment in early pregnancy: a populationbased study. Lancet Infectious Diseases 12, 388-396.

McGregor, I. A. (1984). Epidemiology, malaria and pregnancy. American Fournal of Tropical Medicine and Hygiene 33, 517-525.

Megnekou, R., Staalsoe, T., Taylor, D. W., Leke, R. and Hviid, L. (2005). Effects of pregnancy and intensity of Plasmodium falciparum transmission on immunoglobulin $\mathrm{G}$ subclass responses to variant surface antigens. Infection and Immunity 73, 4112-4118.

Menendez, C., Bardaji, A., Sigauque, B., Romagosa, C., Sanz, S., Serra-Casas, E., Macete, E., Berenguera, A., David, C., Dobano, C., Naniche, D., Mayor, A., Ordi, J., Mandomando, I., Aponte, J. J., Mabunda, S. and Alonso, P. L. (2008). A randomized placebo-controlled 
trial of intermittent preventive treatment in pregnant women in the context of insecticide treated nets delivered through the antenatal clinic. PLoS ONE 3, e1934.

Moncunill, G., Mayor, A., Jimenez, A., Nhabomba, A., CasasVila, N., Puyol, L., Campo, J.J., Manaca, M. N., Aguilar, R., Pinazo, M. J., Almirall, M., Soler, C., Munoz, J., Bardaji, A., Angov, E., Dutta, S., Chitnis, C.E., Alonso, P. L., Gascon, J. and Dobano, C. (2013). High antibody responses against Plasmodium falciparum in immigrants after extended periods of interrupted exposure to malaria. PLoS ONE 8, e73624.

Mueller, I., Widmer, S., Michel, D., Maraga, S., McNamara, D. T., Kiniboro, B., Sie, A., Smith, T. A. and Zimmerman, P. A. (2009). High sensitivity detection of Plasmodium species reveals positive correlations between infections of different species, shifts in age distribution and reduced local variation in Papua New Guinea. Malaria fournal 8, 41.

Nagao, Y., Kimura-Sato, M., Chavalitshewinkoon-Petmitr, P., Thongrungkiat, S., Wilairatana, P., Ishida, T., Tan-Ariya, P., de Souza, J. B., Krudsood, S. and Looareesuwan, S. (2008). Suppression of Plasmodium falciparum by serum collected from a case of Plasmodium vivax infection. Malaria Fournal 7, 113

Nair, L. S. and Nair, A.S. (1993). Effects of malaria infection on pregnancy. Indian Fournal of Malariology 30, 207-214.

Ndungu, F. M., Lundblom, K., Rono, J., Illingworth, J., Eriksson, S. and Farnert, A. (2013). Long-lived Plasmodium falciparum specific memory B cells in naturally exposed Swedish travelers. European Fournal of Immunology 43, 2919-2929.

Nosten, F., ter Kuile, F., Maelankirri, L., Decludt, B. and White, N. J. (1991). Malaria during pregnancy in an area of unstable endemicity. Transactions of the Royal Society of Tropical Medicine and Hygiene $\mathbf{8 5}$, 424-429.

Nosten, F., McGready, R., Simpson, J. A., Thwai, K. L., Balkan, S., Cho, T., Hkirijaroen, L., Looareesuwan, S. and White, N. J. (1999) Effects of Plasmodium vivax malaria in pregnancy. Lancet 354, 546-549. Ordi, J., Menendez, C., Ismail, M. R., Ventura, P. J., Palacin, A., Kahigwa, E., Ferrer, B., Cardesa, A. and Alonso, P. L. (2001). Placental malaria is associated with cell-mediated inflammatory responses with selective absence of natural killer cells. Fournal of Infectious Diseases 183, 1100-1107.

Ouedraogo, S., Bodeau-Livinec, F., Briand, V., Huynh, B. T., Koura, G. K., Accrombessi, M. M., Fievet, N., Massougbodji, A., Deloron, P. and Cot, M. (2012). Malaria and gravidity interact to modify maternal haemoglobin concentrations during pregnancy. Malaria Fournal 11, 348.

Parekh, F. K., Hernandez, J. N., Krogstad, D. J., Casapia, W. M. and Branch, O. H. (2007). Prevalence and risk of Plasmodium falciparum and $P$. vivax Malaria among pregnant women living in the hypoendemic communities of the Peruvian Amazon. American Fournal of Tropical Medicine and Hygiene 77, 451-457.

Poespoprodjo, J. R., Fobia, W., Kenangalem, E., Lampah, D. A. Warikar, N., Seal, A., McGready, R., Sugiarto, P., Tjitra, E., Anstey, N. M. and Price, R. N. (2008). Adverse pregnancy outcomes in an area where multidrug-resistant plasmodium vivax and Plasmodium falciparum infections are endemic. Clinical Infectious Diseases 46, 1374-1381. Portugal, S., Drakesmith, H. and Mota, M. M. (2011). Superinfection in malaria: Plasmodium shows its iron will. EMBO Reports 12,1233-1242. Ramharter, M., Grobusch, M.P., Kiessling, G., Adegnika, A. A., Moller, U., Agnandji, S. T., Kramer, M., Schwarz, N., Kun, J. F., Oyakhirome, S., Issifou, S., Borrmann, S., Lell, B., Mordmuller, B. and Kremsner, P. G. (2005). Clinical and parasitological characteristics of puerperal malaria. Fournal of Infectious Diseases 191, 1005-1009.

Rasti, N., Namusoke, F., Chene, A., Chen, Q., Staalsoe, T., Klinkert, M. Q., Mirembe, F., Kironde, F. and Wahlgren, M. (2006). Nonimmune immunoglobulin binding and multiple adhesion characterize Plasmodium falciparum-infected erythrocytes of placental origin. Proceedings of the National Academy of Sciences of the United States of America 103, 13795-13800.

Richards, J.S., Stanisic, D. I., Fowkes, F. J., Tavul, L., Dabod, E., Thompson, J. K., Kumar, S., Chitnis, C. E., Narum, D. L., Michon, P., Siba, P. M., Cowman, A.F., Mueller, I. and Beeson, J. G. (2010). Association between naturally acquired antibodies to erythrocyte-binding antigens of Plasmodium falciparum and protection from malaria and highdensity parasitemia. Clinical Infectious Diseases 51, e50-e60.

Ricke, C. H., Staalsoe, T., Koram, K., Akanmori, B. D., Riley, E. M., Theander, T. G. and Hviid, L. (2000). Plasma antibodies from malariaexposed pregnant women recognize variant surface antigens on Plasmodium falciparum-infected erythrocytes in a parity-dependent manner and block parasite adhesion to chondroitin sulfate A. Fournal of Immunology (Baltimore, Md.: 1950) 165, 3309-3316.
Riley, E. M., Schneider, G., Sambou, I. and Greenwood, B. M. (1989). Suppression of cell-mediated immune responses to malaria antigens in pregnant Gambian women. American Fournal of Tropical Medicine and Hygiene 40, 141-144.

Roberts, C. W., Satoskar, A. and Alexander, J. (1996). Sex steroids, pregnancy-associated hormones and immunity to parasitic infection. Parasitol Today 12, 382-388.

Robinson, D. P. and Klein, S. L. (2012). Pregnancy and pregnancyassociated hormones alter immune responses and disease pathogenesis. Hormones and Behavior 62, 263-271.

Rogerson, S. J. (2010). Malaria in pregnancy and the newborn. Advances in Experimental Medicine and Biology 659, 139-152.

Rogerson, S. J., Beeson, J. G., Mhango, C. G., Dzinjalamala, F. K. and Molyneux, M.E. (2000). Plasmodium falciparum rosette formation is uncommon in isolates from pregnant women. Infection and Immunity 68, 391-393.

Rogerson, S. J., Pollina, E., Getachew, A., Tadesse, E., Lema, V. M. and Molyneux, M.E. (2003). Placental monocyte infiltrates in response to Plasmodium falciparum malaria infection and their association with adverse pregnancy outcomes. American Fournal of Tropical Medicine and Hygiene 68, 115-119.

Ross, R. and Thomson, D. (1910). Some enumerative studies on malarial fever. Proceedings of the Royal Society of London. Series B, Containing Papers of a Biological Character 83, 159-173.

Rowe, J. A., Obiero, J., Marsh, K. and Raza, A. (2002). Short report: positive correlation between rosetting and parasitemia in Plasmodium falciparum clinical isolates. American Fournal of Tropical Medicine and Hygiene 66, 458-460.

Salanti, A., Staalsoe, T., Lavstsen, T., Jensen, A. T., Sowa, M.P., Arnot, D. E., Hviid, L. and Theander, T. G. (2003). Selective upregulation of a single distinctly structured var gene in chondroitin sulphate Aadhering Plasmodium falciparum involved in pregnancy-associated malaria. Molecular Microbiology 49, 179-191.

Semblat, J.P., Raza, A., Kyes, S. A. and Rowe, J. A. (2006). Identification of Plasmodium falciparum var1CSA and var2CSA domains that bind IgM natural antibodies. Molecular and Biochemical Parasitology 146, 192-197.

Serra-Casas, E., Menendez, C., Dobano, C., Bardaji, A., Quinto, L., Ordi, J., Sigauque, B., Cistero, P., Mandomando, I., Alonso, P. L. and Mayor, A. (2011). Persistence of Plasmodium falciparum parasites in infected pregnant Mozambican women after delivery. Infection and Immunity 79, 298-304.

Shanks, G. D. and White, N. J. (2013). The activation of vivax malaria hypnozoites by infectious diseases. Lancet Infectious Diseases 13, 900-906. Sherman, I. W., Eda, S. and Winograd, E. (2003). Cytoadherence and sequestration in Plasmodium falciparum: defining the ties that bind. Microbes and Infection 5, 897-909.

Simpson, J. A., Silamut, K., Chotivanich, K., Pukrittayakamee, S. and White, N. J. (1999). Red cell selectivity in malaria: a study of multiple-infected erythrocytes. Transactions of the Royal Society of Tropical Medicine and Hygiene 93, 165-168.

Singh, N., Shukla, M. M., Srivastava, R. and Sharma, V.P. (1995). Prevalence of malaria among pregnant and non-pregnant women of district Jabalpur, Madhya Pradesh. Indian Fournal of Malariology 32, 6-13.

Singh, N., Saxena, A., Chand, S. K., Valecha, N. and Sharma, V.P. (1998). Studies on malaria during pregnancy in a tribal area of central India (Madhya Pradesh). Southeast Asian Fournal of Tropical Medicine and Public Health 29, 10-17.

Singh, N., Shukla, M. M. and Sharma, V.P. (1999). Epidemiology of malaria in pregnancy in central India. Bulletin of the World Health Organization 77, 567-572.

Singh, N., Mehra, R. K. and Srivastava, N. (2001). Malaria during pregnancy and infancy, in an area of intense malaria transmission in central India. Annals of Tropical Medicine and Parasitology 95, 19-29.

Singh, N., Saxena, A. and Shrivastava, R. (2003). Placental Plasmodium vivax infection and congenital malaria in central India. Annals of Tropical Medicine and Parasitology 97, 875-878.

Smith, T., Hii, J. L., Genton, B., Muller, I., Booth, M., Gibson, N. Narara, A. and Alpers, M.P. (2001). Associations of peak shifts in age-prevalence for human malarias with bednet coverage. Transactions of the Royal Society of Tropical Medicine and Hygiene 95, 1-6.

Soares, I. S., da Cunha, M. G., Silva, M. N., Souza, J. M., Del Portillo, H. A. and Rodrigues, M. M. (1999). Longevity of naturally acquired antibody responses to the $\mathrm{N}$ - and C-terminal regions of Plasmodium vivax merozoite surface protein 1. American Fournal of Tropical Medicine and Hygiene 60, 357-363.

Souza, R. M., Ataide, R., Dombrowski, J. G., Ippolito, V., Aitken, E. H., Valle, S. N., Alvarez, J. M., Epiphanio, S. and Marinho, C. R. 
(2013). Placental histopathological changes associated with Plasmodium vivax infection during pregnancy. PLoS Neglected Tropical Diseases 7, e2071

Stanisic, D. I., Richards, J. S., McCallum, F. J., Michon, P., King, C. L., Schoepflin, S., Gilson, P. R., Murphy, V. J., Anders, R. F., Mueller, I. and Beeson, J. G. (2009). Immunoglobulin G subclassspecific responses against Plasmodium falciparum merozoite antigens are associated with control of parasitemia and protection from symptomatic illness. Infection and Immunity 77, 1165-1174.

Steketee, R. W., Wirima, J. J., Bloland, P. B., Chilima, B., Mermin, J.

H., Chitsulo, L. and Breman, J. G. (1996). Impairment of a pregnant woman's acquired ability to limit Plasmodium falciparum by infection with human immunodeficiency virus type-1. American fournal of Tropical Medicine and Hygiene 55, 42-49.

Steketee, R.W., Nahlen, B. L., Parise, M. E. and Menendez, C. (2001). The burden of malaria in pregnancy in malaria-endemic areas. American Fournal of Tropical Medicine and Hygiene 64, 28-35.

Stevenson, L., Huda, P., Jeppesen, A., Laursen, E., Rowe, J. A., Craig, A., Streicher, W., Barfod, L. and Hviid, L. (2014). Investigating the function of F-specific binding of IgM to Plasmodium falciparum erythrocyte membrane protein 1 mediating erythrocyte rosetting. Cellular Microbiology. doi: 10.1111/cmi.12403.

Taylor, R. R., Egan, A., McGuinness, D., Jepson, A., Adair, R., Drakely, C. and Riley, E. (1996). Selective recognition of malaria antigens by human serum antibodies is not genetically determined but demonstrates some features of clonal imprinting. International Immunology 8, 905-915.

Taylor, D. W., Zhou, A., Marsillio, L. E., Thuita, L. W., Leke, E. B., Branch, O., Gowda, D. C., Long, C. and Leke, R. F. (2004). Antibodies that inhibit binding of Plasmodium falciparum-infected erythrocytes to chondroitin sulfate $\mathrm{A}$ and to the $\mathrm{C}$ terminus of merozoite surface protein 1 correlate with reduced placental malaria in Cameroonian women. Infection and Immunity 72, 1603-1607.

Teo, A., Hasang, W., Randall, L. M., Feng, G., Bell, L., Unger, H., Langer, C., Beeson, J. G., Siba, P. M., Mueller, I., Molyneux, M. E., Brown, G. V. and Rogerson, S. J. (2014). Decreasing malaria prevalence and its potential consequences for immunity in pregnant women. Fournal of Infectious Diseases 210, 1444-1455.

Thanapongpichat, S., McGready, R., Luxemburger, C., Day, N.P., White, N. J., Nosten, F., Snounou, G. and Imwong, M. (2013). Microsatellite genotyping of Plasmodium vivax infections and their relapses in pregnant and non-pregnant patients on the Thai-Myanmar border. Malaria fournal 12, 275.

Tippett, E., Fernandes, L. A., Rogerson, S. J. and Jaworowski, A. (2007). A novel flow cytometric phagocytosis assay of malaria-infected erythrocytes. Fournal of Immunological Methods 325, 42-50.

Tobon-Castano, A., Solano, M. A., Sanchez, L. G. and Trujillo, S. B. (2011). Intrauterine growth retardation, low birth weight and prematurity in neonates of pregnant women with malaria in Colombia. Revista da Sociedade Brasileira de Medicina Tropical 44, 364-370.

Traill, L. M. (1975). Reticulocytes in healthy pregnancy. Medical Fournal of Australia 2, 205-206.

Tutterrow, Y. L., Avril, M., Singh, K., Long, C. A., Leke, R. J., Sama, G., Salanti, A., Smith, J. D., Leke, R. G. and Taylor, D. W. (2012a). High levels of antibodies to multiple domains and strains of
VAR2CSA correlate with the absence of placental malaria in Cameroonian women living in an area of high Plasmodium falciparum transmission. Infection and Immunity 80, 1479-1490.

Tutterrow, Y.L., Salanti, A., Avril, M., Smith, J. D., Pagano, I. S., Ako, S., Fogako, J., Leke, R. G. and Taylor, D. W. (2012b). High avidity antibodies to full-length VAR2CSA correlate with absence of placental malaria. PLoS ONE 7, e40049.

Udeinya, I. J., Schmidt, J. A., Aikawa, M., Miller, L. H. and Green, I. (1981). Falciparum malaria-infected erythrocytes specifically bind to cultured human endothelial cells. Science 213, 555-557.

Udomsanpetch, R., Thanikkul, K., Pukrittayakamee, S. and White, N. J. (1995). Rosette formation by Plasmodium vivax. Transactions of the Royal Society of Tropical Medicine and Hygiene 89, 635-637.

Umbers, A. J., Aitken, E. H. and Rogerson, S. J. (2011). Review: malaria in pregnancy: small babies, big problem. Trends in Parasitology 27, 168-175.

Vallely, L., Ahmed, Y. and Murray, S. F. (2005). Postpartum maternal morbidity requiring hospital admission in Lusaka, Zambia - a descriptive study. BMC Pregnancy Childbirth 5, 1.

Vleugels, M. P., Eling, W. M., Rolland, R. and de Graaf, R. (1987). Cortisol and loss of malaria immunity in human pregnancy. British Fournal of Obstetrics and Gynaecology 94, 758-764.

Vleugels, M. P., Brabin, B., Eling, W. M. and de Graaf, R. (1989) Cortisol and Plasmodium falciparum infection in pregnant women in Kenya. Transactions of the Royal Society of Tropical Medicine and Hygiene 83, 173-177.

Walter, P. R., Garin, Y. and Blot, P. (1982). Placental pathologic changes in malaria. A histologic and ultrastructural study. American fournal of Pathology 109, 330-342.

Watkinson, M. and Rushton, D. I. (1983). Plasmodial pigmentation of placenta and outcome of pregnancy in West African mothers. British Medical Fournal (Clinical Research Edition) 287, 251-254.

White, M. T., Griffin, J. T., Akpogheneta, O., Conway, D. J., Koram, K. A., Riley, E. M. and Ghani, A. C. (2014). Dynamics of the antibody response to Plasmodium falciparum infection in African children. Fournal of Infectious Diseases 210, 1115-1122. doi: 10.1093/infdis/jiu219. WHO (2011). Guideline: Vitamin A supplementation in postpartum women

WHO (2014). World Malaria Report.

Wipasa, J., Suphavilai, C., Okell, L.C., Cook, J., Corran, P. H., Thaikla, K., Liewsaree, W., Riley, E. M. and Hafalla, J. C. (2010). Long-lived antibody and B Cell memory responses to the human malaria parasites, Plasmodium falciparum and Plasmodium vivax. PLoS Pathogens 6, e1000770.

Yasnot, M. F., Perkins, D. J., Corredor, M., Yanow, S., CarmonaFonseca, J. and Maestre, A. (2013). The effects of Plasmodium vivax gestational malaria on the clinical and immune status of pregnant women in Northwestern Colombia. Colomb Med (Cali) 44, 172-177.

Yeo, T.W., Lampah, D. A., Tjitra, E., Piera, K., Gitawati, R., Kenangalem, E., Price, R. N. and Anstey, N. M. (2010). Greater endothelial activation, Weibel-Palade body release and host inflammatory response to Plasmodium vivax, compared with Plasmodium falciparum: a prospective study in Papua, Indonesia. Fournal of Infectious Diseases 202, 109-112. 